Research Report No. 8/2011

\title{
A Damp Squib: Environmental Law from a Human Evolutionary Perspective
}

Benjamin J. Richardson

Follow this and additional works at: http:/ / digitalcommons.osgoode.yorku.ca/clpe

\section{Recommended Citation}

Richardson, Benjamin J., "A Damp Squib: Environmental Law from a Human Evolutionary Perspective" (2011). Comparative Research in Law \& Political Economy. Research Paper No. 8/2011.

http://digitalcommons.osgoode.yorku.ca/clpe/46 


\section{OSGOODE}

\section{OSGOODE HALL LAW SCHOOL}

Comparative Research in Law \& Political Economy

RESEARCH PAPER SERIES

Research Paper No. 08/2011

\section{A Damp Squib: Environmental Law from a Human Evolutionary Perspective}

Benjamin J. Richardson

\section{Editors:}

Peer Zumbansen (Osgoode Hall Law School, Toronto, Director, Comparative Research in Law and Political Economy)

John W. Cioffi (University of California at Riverside)

Lisa Philipps (Osgoode Hall Law School, Associate Dean Research)

Nassim Nasser (Osgoode Hall Law School, Toronto, Production Editor) 
Osgoode CLPE Research Paper 08/2011

Vol. 07 No. 03 (2011)

Benjamin J. Richardson

\title{
A Damp Squib: Environmental Law from a Human Evolutionary Perspective
}

\begin{abstract}
Humans have become the Earth's dominant animals, yet we remain perched on the precipice of an anthropogenic collapse in planetary ecological systems. For lawyers, this raises a question: why hasn't environmental law succeeded? The law's limitations in this area cannot satisfactorily be explained merely due to poorly designed institutions, lack of political will, or economic disincentives, among prevalent explanations in the literature. Rather, its flaws should also be understood in terms of human psychology, as derived from the interaction of complex biological and cultural evolutionary processes. While some legal scholars have drawn insights from behavioural economics or social psychology, few have examined the deeper evolutionary perspective. Our environmental behavior is influenced by what our ancestors have done over thousands of years. But behaviors that were adaptive in ancestral environments can today be irrational or maladaptive, including risk-taking, myopia, and lack of extended altruism. Using insights from evolutionary psychology may also help us to design more behaviourally-effective environmental laws to stave off the impending environmental crisis.
\end{abstract}

Keywords: Environmental law, Flaws, Human psychology, Behavioural economics, Social psychology, Evolutionary perspective

JEL classification: K39

\author{
Benjamin J. Richardson \\ Professor, \\ Osgoode Hall Law School, \\ York University, \\ Canada.
}




\title{
A Damp Squib: Environmental Law from a Human Evolutionary Perspective
}

\author{
Benjamin J. Richardson*
}

\section{THE INSCRUTABLE HUMAN CONDITION}

In William Golding's allegorical novel, Lord of the Flies, a group of English schoolboys stranded on a deserted island try to govern themselves but regress into savagery. ${ }^{1}$ Isolated from modern civilization, the semblance of order and control among the boys soon degenerates and violence ensues. The novel's plot still resonates with many readers today as a disturbing parable of the darker side of human nature. without the veneer of civilized society and its rules, humankind is unveiled by Golding as a beast. Similarly, it could be said that the more unsavory side of human nature is illuminated by our relationship with the nature, and the seeming ineffectiveness of our laws and institutions to curb the environmental burden of modern civilization.

Despite appearances, environmental law in much of the world is a damp squib-in other words, it doesn't work properly and fails to ensure sustainable development. In theory, environmental law can be a means of serving both our own self-interest, such as by safeguarding drinkable water or breathable air, as well as extending enlightened protection to other creatures, such as conserving endangered species or advancing animal welfare. In practice, the problems environmental law is meant to resolve have by-and-large worsened, despite the increasing swathe of regulations and international treaties implemented in recent decades. ${ }^{2}$ One likely reason is that environmental law-makers have not been sufficiently attentive to human nature and the behavioral drivers behind our environmental practices.

Understandings of human nature in Western thought have long been contested. The two most contrasting views are that people are basically nice if we are not corrupted by "civilization", or entirely nasty if we are not tamed by the presence of authority. It is a debate that has most famously pitted English philosopher Thomas Hobbes (1588-1679), arguing for nastiness, against French thinker Jean-Jacques Rousseau (1712-1778), championing niceness. ${ }^{3}$ Alternatively refuting any form of innatism, seventeenth-century philosopher John Locke postulated that the mind was a blank slate (except for a predisposition to acquire property) out of which life experience moulds one's character. ${ }^{4}$ But each of these views about human nature shared the

* Professor, Osgoode Hall Law School, York University, Canada.

$1 \quad$ WILLIAM GOLDING, LORD OF THE FLIES (1954).

2 On the evolution of modern environmental law, see Neil Gunningham, Environment Law, Regulation and Governance: Shifting Architectures, 21(2) J. ENVTL L. 179 (2009). Some states have even gone so far as to enshrine environmental principles and duties in their national constitutions, elevating environmental law to a supreme law: Ernst Brandl \& Hartwin Bungert, Constitutional Entrenchment of Environmental Protection: A Comparative Analysis of Experiences Abroad, 16 HARV. ENVTL L. REV. 1 (2002).

3 See THOMAS HOBBES, LEVIATHAN (1651); JEAN-JACQUES ROUSSEAU, DISCOURSE ON INEQUALITY (1754).

4 JOHN LOCKE, AN ESSAY CONCERNING HUMAN UNDERSTANDING (1690). 
assumption that the individual is the fundamental reference point. As in Lord of the Flies, the Hobbesian view has tended to be the most influential in Western thought, and it has profoundly influenced the design of law.

Yet human nature, as revealed by subsequent academic research and personal experience, is clearly much more nuanced and complex than these stark perspectives. Sometimes we can be aggressive, selfish, and even self-delusional. But people can also empathize, cooperate, and show altruism, which in the opinion of some makes us a "moral animal" 5 with the faculty to consider our impacts on other creatures and to take evasive action. But the relative significance of our ensemble of lighter and darker instincts, how they are shaped culturally, and their precise implications for our relationship with the environment, remain highly debatable.

A good vantage point for understanding human nature is its most primitive form. While human behavior can be analyzed from a wide array of disciplinary perspectives, including behavioral economics, political science, and social psychology, the evolutionary perspective can offer deeper insights into the ultimate roots of the human condition. Whereas the field of evolutionary biology is concerned with understanding the various physiological features of a whole organism, evolutionary psychology, which is the focus of my article, looks at one special feature-the human mind, as a collection of evolved psychological adaptations, the contexts that activate those adaptations, and their behavioral manifestations. ${ }^{6}$

Our environmental behavior is influenced by what our ancestors have done over thousands or even millions of years. For ninety-nine percent of our evolutionary history, people lived in hunter-gatherer societies; ${ }^{7}$ yet human culture and the development of agriculture, as we know it, is less than 10,000 years old. Our evolutionary heritage creates a number of behavioral predispositions, some of which under contemporary conditions are environmentally maladaptive, in the sense that they hinder our ability to recognize the gravity of some of our environmental threats and how we might avert them. Further, some of those behavioral predispositions are being reinforced and amplified by culture, which has given us the technological and institutional means to wreak much greater environmental harm than was possible as frugal hunter-gatherers.

We thus remain perched on the precipice of an anthropogenic collapse in planetary ecological systems that must provoke enquiry about whether humanity itself is sustainable, in

5 RONALD WRIGHT, THE MORAL ANIMAL. WHY WE ARE THE WAY WE ARE: THE NEW SCIENCE OF EVOLUTIONARY PSYCHOLOGY (1994).

6 DAVID M. BUSS, EVOLUTIONARY PSCYHOLOGY: THE NEW SCIENCE OF THE MIND 49-50 (2004). 
evolutionary terms. ${ }^{8}$ Our planetary domination is such that some biohistorians label the present epoch of Earth's history as the "Anthropocene". ${ }^{9}$ While humankind has been altering nature for millennia, ${ }^{10}$ since the early twentieth century the range and magnitude of our ecological footprint has grown exponentially. In 2005, the Board of the Millennium Ecosystem Assessment warned that "human activity is putting such strain on the natural functions of the Earth that the ability of the planet's ecosystems to sustain future generations can no longer be taken for granted". ${ }^{11}$ Species are disappearing between 100 to 1,000 times faster than in pre-human times, $^{12}$ some 40 percent of the planet's forests of 8,000 years ago have gone, ${ }^{13}$ and atmospheric carbon dioxide is at its highest level in some 650,000 years. ${ }^{14}$ Fuelling these and many other impacts are soaring human numbers and accompanying economic activity; in the twentieth century the world's population grew by a factor of four, from some 1.5 billion to 6 billion, and the global economy enlarged by a factor of $13 .{ }^{15}$

With emerging economies such as China and India rapidly industrializing, and thereby intensifying the global environmental burden, grave ecological tipping points may be irreparably passed soon. The disparate corollaries of these environmental changes and stresses for humankind will include food shortages, poisoned food chains, dissemination of pathogens, intense physical damage from storms and other climatic changes, conflicts over water and other increasingly scarce natural resources, as well as poverty and a widening gulf between the rich and the poor. ${ }^{16}$ The likelihood of these problems-which will surely dwarf the impact of the Great Depression or previous two World Wars-should not surprise us. Indeed, archaeological

8 Charles Fowler \& Larry Hobbs, Is Humanity Sustainable? in PROCEEDINGS OF THE ROYAL SOCIETY OF LONDON, SERIES B: BIOLOGICAL SCIENCES 270 (2003).

Will Steffen, Paul J. Crutzen \& John R. McNeill, The Anthropocene: Are Humans Now Overwhelming the Great Forces of Nature, 36(8) AMBIO 614 (2007).

E.g., TIMOTHY FLANNERY, THE FUTURE EATERS: AN ECOLOGICAL HISTORY OF THE AUSTRALASIAN LANDS AND PEOPLE (1995) (discussing the historical ecological impacts of indigenous peoples in Oceania).

LIVING BEYOND OUR MEANS: NATURAL ASSETS AND HUMAN WELL-BEING. STATEMENT FROM THE BOARD 5 (Millennium Ecosystem Assessment ed., 2005).

EXTINCTION RATES 10-22 (John H. Lawton \& Robert M. May eds., 1995); see also Juliet Jowlett, Humans Driving Extinction Faster Than Species Can Evolve, Say Experts, Guardian (March 7, 2010), available at http://www.guardian.co.uk/environment/2010/mar/07/extinction-species-evolve

Anatoly Shvidenko, Charles V. Barber \& Reidar Persson, Forests, in ECOSYSTEMS AND HUMAN WELL-BEING: CURRENT STATE AND TRENDS 585, 588 (Millennium Ecosystem Assessment ed., 2005).

Gary Gardner \& Thomas Prugh, Seeding the Sustainable Economy, in STATE OF THE WORLD 20084 (Worldwatch Institute ed., 2008). JOHN MCNEILL, SOMETHING NEW UNDER THE SUN 360 (2000). 
records suggest that civilizations that did not live within environmental constraints suffered ruin. $^{17}$

Given what is thus at stake, why is environmental law failing? We should not be misled by its occasional triumphs, such as the accelerated phasing out of atmospheric ozone-depleting chemicals, $^{18}$ the rescue of iconic species from the brink of extinction, ${ }^{19}$ or the international rhetoric about "sustainable development" as environmental law's guiding objective. ${ }^{20}$ At most, we could concede that environmental law has "succeeded" in mitigating what would be a direr prognosis. Its failure to substantially curb such trends cannot entirely be explained simply as a result of institutional or political failings, whether owing to ineptly designed regulation, insufficient resources, or economic disincentives, among prevalent explanations in the literature. ${ }^{21}$ Rather, as I will show in this article, environmental law's limitations stem more elementarily from unresolved problems in the human condition as a product of the interaction of biological and cultural evolutionary processes.

While evolutionary science cannot by itself supply a normative direction for environmental law, a better understanding of human behavior can aid society's efforts to change behavior. Although we are seemingly at the pinnacle of our numbers, extent and dominion over nature, humankind is imbued with unsustainable tendencies which environmental law has yet to address fully. Environmental law is hampered where it ignores or misunderstands the behavioral tendencies of the actors it seeks to influence. An evolutionary perspective can enable us to identify and analyze which behaviors are deeply ingrained and most resistant to change through regulatory sanctions, economic incentives or other techniques, and which

17 See CHARLES L. REDMAN, HUMAN IMPACT ON ANCIENT ENVIRONMENTS (1999); JARED DIAMOND, COLLAPSE: HOW SOCIETIES CHOOSE TO FAIL OR SUCCEED 157-77 (2005); but compare QUESTIONING COLLAPSE: HUMAN RESILIENCE, ECOLOGICAL VULNERABILITY AND THE AFTERMATH OF EMPIRE (Patricia A. McAnany \& Norman Yoffee eds., 2010).

Montreal Protocol on Substances That Deplete the Ozone Layer, 28 I.L.M. 649 (1989); for an analysis on why this instrument succeeded, see SCOTT BARRETT, ENVIRONMENT AND STATECRAFT: THE STRATEGY OF ENVIRONMENTAL TREATY-MAKING 221-52 (2003),

A national symbol of the United States, the American Bald Eagle (Haliaeetus leucocephalus) was virtually extinct when the Endangered Species Preservation Act, 80 Stat. 926; 16 U.S.C. 668aa(c) I) was passed in late 1966. Today, in 2010, all populations except those in the far southwestern United States were transferred from the endangered to the threatened species list.

See Herman E. Daly, Toward Some Operational Principles of Sustainable Development, 2 ECOL. ECON. 1 (1990); MARIE-CLAIRE CORDONIER SEGGER \& ASHFAQ KHALFAN, SUSTAINABLE DEVELOPMENT LAW: PRINCIPLES, PRACTICES, AND PROSPECTS (2005).

See e.g., DAVID BOYD, UNNATURAL LAW: RETHINKING CANADIAN ENVIRONMENTAL LAW AND POLICY (2003); Bruce A. Ackerman \& Richard B. Stewart, Reforming Environmental Law: The Democratic Case for Market Incentives, 37 STAN. L. REV. 1333 (1985); ALEXANDER GILLESPIE, THE ILLUSION OF PROGRESS; UNSUSTAINABLE DEVELOPMENT IN INTERNATIONAL LAW (2001). 
behaviors are more amenable to legal influences. Some improvements to environmental law will not only depend on a greater understanding of human behavior, but also on rapid cultural innovations that more conscientiously tap into the kinder and moral side of human nature.

In the rest of this article, I will examine the limitations of environmental law, and its potential reform, from the perspective of evolutionary psychology. I argue that while the human condition has some environmentally maladaptive traits, which environmental law has failed to acknowledge, the nuanced and complex human condition contains an array of cooperative and altruistic impulses which law-makers can harness to build successful environmental law. In other words, we are not trapped by any biologically deterministic path to ruin the environment; humankind has choices, and can innovate culturally to lessen its environmental burden. Part II of this article theorizes human nature and focuses on the insights from evolutionary psychology, and highlights the range of behavioral tendencies of humans. Part III examines humans' environmental legacy, and explains how environmental misuse is associated with several behavioral maladaptions that societies have yet to adequately control. The redesign of environmental law to make it more behaviorally effective is discussed in Part IV. The focus is on distillation of several core principles to guide reform. A brief conclusion is provided in Part $\mathrm{V}$, as well as comments on how we should view our future if we cannot resolve our environmental challenges.

\section{THEORIZING HUMAN NATURE}

\section{A. INTRODUCTION}

Environmental law is often well informed by the latest scientific knowledge about how ecosystems function-for example, water protection rules are now commonly based on the workings of the hydrological cycle, and environmental impact assessment procedures help to predict the ecological changes posed by developments. ${ }^{22}$ But commensurate effort has not been provided by environmental law-makers in understanding how humans function, even though such understanding is essential if their regulation is to be behaviorally effective. ${ }^{23}$ Critiques of environmental law's record commonly rest on institutional, economic, and political variables, rather than directly implicating the underlying human behavior. The most perspicacious views of environmental law tend to come from scholars that have an interdisciplinary perspective, while drawing on philosophy and anthropology. ${ }^{24}$

22 Nükhet Yilmaz Turgut, The Influence of Ecology on Environmental Law: Challenges to the Concept of Traditional Law, 10(2) ENVTL L. REV. 112 (2008); J.B. RUHL, STEVEN KRAFT \& CHRISTOPHER L. LANT, THE LAW AND POLICY OF ECOSYSTEM SERVICES (2007).

23 Gruter explains that "The effectiveness of law will be proportional to the degree to which the function of a particular law complements the function of the behavior that the law intends to regulate." MARGARET GRUTER, LAW AND THE MIND: BIOLOGICAL ORIGINS OF HUMAN BEHAVIOR 21 (1991).

E.g., KLAUS BOSSELMANN, THE PRINCIPLE OF SUSTAINABILITY: TRANSFORMING LAW AND GOVERNANCE (2008); MARK SAGOFF, THE ECONOMY OF THE EARTH: PHILOSOPHY, LAW AND THE ENVIRONMENT (1988); SUSTAINING LIFE ON EARTH: ENVIRONMENTAL AND HUMAN HEALTH THROUGH GLOBAL GOVERNANCE 
Much legal theory, including research on environmental law, presumes or constructs notions of "human nature" that are the subject of regulation or other legal influences. Legal policymakers, however, are often unaware of their dependence on behavioral models and can be complacent in their assumption that they rely on accurate models. One very influential paradigm of human nature in the development of modern environmental law is Garrett Hardin's parable of the "Tragedy of the Commons". ${ }^{25}$ Hardin's tale of the inevitable environmental degradation of a common grazing pasture open to all herders is based on a particular view of human nature as selfish, materialistic, and uncooperative. It is a stance sometimes associated with the increasingly rebuked neoclassical economics notion of homo economicus. $^{26}$ The problem Hardin examined has since been debated extensively through various analytical lens, including the "prisoner's dilemma" and coordinating "collective action". ${ }^{27}$ Hardin's thesis and its intellectual legacy has been unhelpful for its simplistic assumptions about human nature, in addition to its conceptual confusion about the difference between an open access resource and one that is managed communally. ${ }^{28}$

Philosophers have long debated what human nature is, and have often looked to our most primitive and seemingly unadulterated form for answers. Some mythologize a golden age from which we have been corrupted by civilization. Moral sentimentalists such as Francis Hutcheson and David Hume argued that people have natural inclinations to be sympathetic and concerned for others' welfare. ${ }^{29}$ More than any other Enlightenment thinker, Jean-Jacques Rousseau concluded that our original state of nature was utopian, born without original sin and having benevolent impulses. ${ }^{30}$ According to Rousseau, it is only the trappings of "civilization", such as property ownership, monarchical despotism, and religious authority, which have brought discord and depravity. Alternatively, some believe that civilization has improved the human character from its supposedly barbaric, primitive beginnings. Voltaire, for instance, believed that human nature was not fundamentally corrupt: "Man is not born evil; he becomes evil, as

(Colin L. Soskolne, et al. eds., 2008); SEAN COYLE \& KAREN MORROW, THE PHILOSOPHICAL FOUNDATIONS OF ENVIRONMENTAL LAW: PROPERTY, RIGHTS AND NATURE (2004).

Garrett Hardin, The Tragedy of the Commons, 162 SCIENCE 1243 (1968).

Chris Doucouliagos, Note on the Evolution of Homo Economicus, 28 J. ECON. ISSUES 469 (1994). For criticism, see Herbert Gintis, Beyond Homo Economicus, 35(3) ECOL. ECON. 311 (2000)

See e.g,, ELINOR OSTROM, GOVERNING THE COMMONS: THE EVOLUTION OF INSTITUTIONS FOR COLLECTIVE ACTION (1990); ANATOL RAPOPORT \& ALBERT M. CHAMMAH, PRISONER'S DILEMMA: A STUDY IN CONFLICT AND COOPERATION (1965).

MATT RIDLEY, THE ORIGINS OF VIRTUE 232 (1996).

See LOUIS SCHNEIDER, THE SCOTTISH MORALISTS ON HUMAN NATURE AND SOCIETY 7-9 (1967).

ROUSSEAU, supra note 3. 
he becomes sick".$^{31}$ In this bleaker view of human nature, any "human morality is presented as just a thin crust underneath of which boil antisocial, amoral and egoistic passions" ${ }^{32}$ Thomas Hobbes saw humankind as naturally selfish, brutal, and nasty, the solution to which, he believed, was authoritarian government to tame man and avoid a state of perpetual fratricidal conflict. Hobbes' somber view of humankind has influenced many subsequent environmental thinkers, from Thomas Robert Malthus ${ }^{33}$ to William Ophuls, ${ }^{34}$ who have raised the specter of highly authoritarian rule to save a rapidly depleted and overpopulated planet.

None of these opinions about the human condition and human prehistory are entirely accurate. They fail to acknowledge the nuanced diversity of practices and social conditions around the world documented by behavioral scientists. ${ }^{35}$ Evolutionary psychology attempts to integrate a range of fragmentary human disciplines including anthropology, behavioral economics, political science, cognitive psychology, and biology into a coherent, broad theoretical framework for understanding human behavior. It has sought to challenge our understandings of sex, family, friendship, and other human traits by showing that much behavior is bred in the bone through evolutionary processes. In its early years, as an academic discipline, evolutionary psychology was influenced by research on primate ethology.

\section{B. LESSONS FROM PRIMATE ETHOLOGY}

Research on primates has influenced theorizing about human social behavior. Because of their consanguinity with humans, related morphology and cognitive abilities, chimpanzees and bonobos have been the main referential models for such research. ${ }^{36}$ About ninety-eight percent of the genetic material found in contemporary humans is shared with these primates, a closeness that led natural historian Jared Diamond to write a book that described people as The Third Chimpanzee. ${ }^{37}$ Nonetheless, deducing human behavior from what has been observed in primates is fraught with methodological difficulties. Scientists remain uncertain as to which apes model our closest ancestors: the mostly peaceful, egalitarian bonobos, or the more violent, authoritarian chimpanzees. We also are unclear about the relative importance of

31 FRANÇOIS-MARIE AROUET, PHILOSOPHICAL DICTIONARY 2: 378 (translated by P. Gay, 1962, original 1764) (Voltaire was his pen name).

32

SUSAN NEIMAN, MORAL CLARITY 257 (2009) (quoting Frans de Waal). This idea, often known as "veneer theory", originated with THOMAS H. HUXLEY, EVOLUTION AND ETHICS (1894).

THOMAS ROBERT MALTHUS, AN ESSAY ON THE PRINCIPLE OF POPULATION (1798).

William Ophuls, Leviathan or Oblivion, in TOWARD A STEADY STATE ECONOMY (Herman E. Daly ed., 1973).

See RICHARD LEWONTIN, HUMAN DIVERSITY (1995); PHILLIP. TÍTULO, ANTHROPOLOGY. THE EXPLORATION OF HUMAN DIVERSITY (2004); WILLIAM DURHAM, COEVOLUTION: GENES, CULTURE, AND HUMAN DIVERSITY (1992).

36 Notably, Craig B. Stanford, The Social Behavior of Chimpanzees and Bonobos: Empirical Evidence and Shifting Assumptions, 39(4) CURRENT ANTHROP. 399 (1998).

JARED DIAMOND, THE RISE AND FALL OF THE THIRD CHIMPANZEE: HOW OUR ANIMAL HERITAGE AFFECTS THE WAY WE LIVE (1991). 
nature and nurture in primates. Anthropologist Melvin Konner concludes, "Few rules about the social lives of monkeys hold up. One species in different environments can vary almost as much as different species do. So there are no assurances about what our five-million-year-old ancestors' social structure was like". ${ }^{38}$

Consequently, theorizing about primate behavior and its applicability to Homo sapiens sapiens is deeply contested. A traditional theory of primatology is that competition and aggression over access to food and sexual partners has shaped the understanding of the origins of group-living and sociality in both human and non-human primates. ${ }^{39}$ In the 1960 s many anthropologists on this basis subscribed to the "killer ape" theory, namely that interpersonal aggression and warfare has predominantly shaped human evolution. ${ }^{40}$ In most primate species, however, cooperative and affiliative interactions, such as grooming, food sharing, cooperative hunting, and shared vigilance against predators, are also common and may have a more formative influence on behavioral interactions. ${ }^{41}$ The evolution of such sociality has been theorized in terms of neurological feedback systems-specifically that hormonal (oxytocin) mechanisms may be facilitative of innate cooperative social responses. ${ }^{42}$

Research on primate ethology has also revealed gender differences in behavior. ${ }^{43}$ One fascinating study by Robert Sapolsky and Lisa Share looked at the impact of a demographic change in a troop of Kenyan baboons. ${ }^{44}$ A severe outbreak of tuberculosis in the $1980 \mathrm{~s}$ decimated the most belligerent and dominant males among the baboons, leading to some

38

39

40

MELVIN KONNER, THE TANGLED WEB: BIOLOGICAL CONSTRAINTS ON THE HUMAN SPIRIT (2nd. ed., 2003).

See Robert S.O. Harding, Three Decades of Anthropological Primatology, 18 REVS. IN ANTHROP. 235 (1991).

See Raymond Dart, The Predatory Transition from Ape to Man, 1 INTER'L ANTHROP. \& LINGUISTIC REV. 201 (1953); ROBERT ARDREY, AFRICAN GENESIS: A PERSONAL INVESTIGATION INTO THE ANIMAL ORIGINS AND NATURE OF MAN (1961). "Civilization" has supposedly served to restrain such tendencies, but whose frailty is exemplified in Golding's Lord of the Flies, supra note 1.

Robert W. Sussman \& Paul A. Garber, Cooperation and Competition in Primate Social Interactions, in PRIMATES IN PERSPECTIVE 636 (Christina J. Campbell, et al. eds., 2006). While cooperation has been observed in chimps (see Alicia P. Melis, Brian Hare \& Michael Tomasello, Chimpanzees Coordinate in a Negotiation Game, 30(6) EVOLUTION \& HUMAN BEHAVIOUR 281 (2009)), it is most strongly associated with gorillas (see ALEXANDER H. HARCOURT \& KELLY J. STEWART, GORILLA SOCIETY: CONFLICT, COMPROMISE AND COOPERATION BETWEEN THE SEXES (2007)).

MEG M. OLMERT, MADE FOR EACH OTHER: THE BIOLOGY OF THE HUMAN-ANIMAL BOND xiii-xvi (2009)

There is also a vast strand of research on people that highlight gender differences in our propensities to cooperate or conflict. "Ecofeminists" such as Val Plumwood argue that feminist analysis can help to illuminate ways to behave more kindly to nature: VAL PLUMWOOD, FEMINISM AND THE MASTERY OF NATURE (1993).

Robert M. Sapolsky \& Lisa J. Share, A Pacific Culture among Wild Baboons: Its Emergence and Transmission, 2(4) PLOS. BIOL. E 106 (2004). 
profound social and behavioral transformations in the survivors. They comprised a few relatively docile males, as well as all the females and juveniles. These baboons became much more peaceful and communal than the former troop, and astonishingly retained their genial ethos over many years, even though a new generation of males took over as well as some outsiders joining the troop. The perpetuation of communal comity suggests that some new process of acculturation in the group was occurring.

Regardless of these and other insights of primate ethology, many scientists argue that since chimpanzees (often regarded as our closest relatives) and humans diverged genetically some six million years ago, each has developed unique social cognitive adaptations. ${ }^{45}$ For example, humans are believed to have become more social because "bipedalism necessitated assistance at birth and alloparenting developed when children needed increasing amounts of care" ${ }^{46} \mathrm{And}$, unlike other primates, humans have developed "the capacity for cumulative cultural learning". ${ }^{47}$ Therefore, in examining our species' capacity for empathy, altruism, cooperation, and other traits useful for addressing environmental problems, it is necessary to look primarily at ourselves for evidence.

\section{INSIGHTS FROM EVOLUTIONARY PSYCHOLOGY}

Like other species, Homo sapiens sapiens is subject to natural selective pressures with regard to its preferences, emotions, cognition, and values, which serve to enhance opportunities for individuals' survival and reproduction. ${ }^{48}$ Drawing upon the pioneering theory of "socio-biology" advanced in the $1970 \mathrm{~s},{ }^{49}$ evolutionary psychologists such as David Buss and Steven Pinker interpret much human behavior as generated by highly specialized psychological adaptations that evolved to solve ongoing challenges in humankind's ancestral environments. ${ }^{50}$ Thus, just as for hearts, lungs, and other bodily organs, cognition and emotions have a genetic basis which has evolved by natural selection, and is universally shared amongst a species. In order to properly understand the functions of the brain, we must understand the environmental conditions in which the brain evolved.

45 Johan De Smedt, Helen De Cruz \& Johan Braeckman, Why The Human Brain is Not an Enlarged Chimpanzee Brain, in HUMAN CHARACTERISTICS: EVOLUTIONARY PERSPECTIVES ON HUMAN MIND AND KIND 168, 169 (Henrik Hogh-Olesen, Jan Tonnesvang \& Preben Bertelsen eds., 2009).

46 De Smedt, De Cruz \& Braeckman, supra note 45, at 174.

47 Id., at 175 .

CHARLES DARWIN, ON THE ORIGINS OF SPECIES BY MEANS OF NATURAL SELECTION, OR THE PRESERVATION OF FAVOURED RACES IN THE STRUGGLE FOR LIFE (1859).

49 Developed by EDWARD O. WILSON, SOCIOBIOLOGY: THE NEW SYNTHESIS (1975).

50 David M. Buss, Evolutionary Personality Psychology, 42 ANN. REV. PSYCHOLOGY 459 (1991); STEVEN PINKER, HOW THE MIND WORKS (1999). See also JEROME BARKOW, LEDA COSMIDES AND JOHN TOOBY, THE ADAPTED MIND: EVOLUTIONARY PSYCHOLOGY AND THE GENERATION OF CULTURE (1992) 
Evolutionary psychologists hypothesize that such environments were the incubator for a range of inherited emotional and cognitive adaptations, such as the capacity for language, and the abilities to infer others' emotions and to discriminate between kin and non-kin. ${ }^{51}$ Evolutionary psychologists see those behaviors and cognition biases that are nearly worldwide and transcend specific cultures, such as fear of spiders and snakes, as reflective of evolved adaptations. While natural selection should foster organic designs and behavior that are functional, in that they enable a creature to become better adapted to its physical environment, evolutionary psychology has revealed behavior in animals, including humans, that is nonfunctional and even dysfunctional-which, as is discussed later in this article, can be especially relevant to understanding some of our harmful environmental practices and ineffective laws.

Much of humanity's evolutionary roots were in the savannas of East Africa, in hunter-gatherer social structures. Humans likely lived in small, highly-interdependent communities, dominated by kin and allies, ${ }^{52}$ but probably in competition with other groups including occasional violent conflict over territory and access to resources..$^{53}$ The momentous dispersal worldwide of anatomically modern Homo sapiens sapiens from Africa occurred about 150,000 years ago, bringing people into contact with unfamiliar environments that helped trigger behavioral adaptations. However, it was not until the emergence of stable, benign climatic conditions during the Holocene that humanity underwent its "Great Leap Forward" ${ }^{54}$ The development of agriculture began about 5,000 BCE, the emergence of writing in the Sumerian culture around $3500 \mathrm{BCE}$, and the construction of the first towns and cities in Egypt around 3100 BCE. ${ }^{55}$ No doubt, formal legal systems also emerged during this period to support economic activities and the more complex social arrangements.

Evolutionary psychology does not imply biological determinism. There is no one human way to which we are tied by our evolutionary history. Much of the resistance to the application of evolutionary theory to understanding contemporary human behavior, explains David Buss, "stems from the misconception that evolutionary theory implies genetic determinism" and that human behavior "is impervious to change" ${ }^{56}$ In fact, evolutionary models of human behavior

51 See CHARLES CRAWFORD, DENNIS L. KREBS, HANDBOOK OF EVOLUTIONARY PSYCHOLOGY: IDEAS, ISSUES, AND APPLICATIONS (1998).

$52 \quad$ WILSON, supra note 49 , at 574.

$53 \quad$ Id. at $564-65$.

54 STEVEN MITHEN, AFTER THE ICE: A GLOBAL HUMAN HISTORY, 20,000-5,000 BC (2003).

55 See PETER S. BELLWOOD, FIRST FARMERS: THE ORIGINS OF AGRICULTURAL SOCIETIES (2005); LEWIS MUMFORD, THE CITY IN HISTORY: ITS ORIGINS, ITS TRANSFORMATIONS, AND ITS PROSPECTS (1961); STEVEN R. FISCHER, A HISTORY OF WRITING (2001). 
recognize that one's behavior is a function of the mutual interaction between biological variation and environmental selection, or, as the issue is often described (sometimes misleadingly), between nature and nurture. Evolutionary science concedes that culture gives us the knowledge and tools to alter those environmental inputs to some extent in order to improve our behavior. ${ }^{57}$ Human beings are an evolutionary success because we are the most generalized of animals; we can and have in the past adapted to extraordinarily diverse circumstances and to rapid change. Biologically, there has been some recent natural selectionnamely in the ethnic varieties of Homo sapiens sapiens, all sprung from our ancestors in Africa. There have also been physiological adaptations in the shorter term. But, basically, it is culture that makes us adaptive, and has spawned the variety of human societies of interest to anthropologists and social historians. ${ }^{58}$

Evolutionary theory can provide several insights into human social behavior including environmental practices that may be overlooked by other academic disciplines such as social psychology, behavioral economics, or political science. One such insight is into the less proximate bases to our behavior-focusing on the why behind the why. Proximate causes may seem random or incomprehensible until placed in a larger, evolutionary context. Observable phenomena may make little sense until we can decipher their ultimate causes. A further advantage of evolutionary theory is that it can transcend general principles to illuminate their specific context. For example, general notions that people seek to "maximize economic utility", as postulated by behavioral economics, might be too general to understand specific human behaviors. What matters as an economic benefit varies according to different social contexts, such as the distinction between how we value relationships with kin and strangers. ${ }^{59}$

An evolutionary perspective can also help us understand the biological bases to culture. Rather than seeing human behavior as wholly a product of our social environment, evolutionary theory reveals that culture has not sprung forth arbitrarily, but, rather, is based on evolved psychological adaptations in our emotions, beliefs, and behaviors. Local social and ecological conditions can generate variations, but the broad parameters are set by biological traits. As Matt Ridley explains, it is not a question of nature versus nurture (i.e., culture), but, rather, nature via nurture. ${ }^{60}$

Nonetheless, embracing evolutionary science does not render the findings of traditional social psychology, behavioral economics, or other disciplines redundant. Indeed, evolutionary

$57 \quad$ Id. at 19.

58 See, e.g., David Hackett Fischer's brilliant investigation of how the United States' amazing regional differences in social/political philosophy can be tied to the exact circumstances of settlement of the different areas of the country: DAVID HACKETT FISCHER, ALBION'S SEED: FOUR BRITISH FOLKWAYS IN AMERICA (1989).

See Martin Daly, Catherine Salmon \& Margo Wilson, Kinship: The Conceptual Hole in Psychological Studies of Social Cognition and Close Relationships, in EVOLUTIONARY SOCIAL PSYCHOLOGY 265 (Jeffery Simpson \& Douglas Kendrick eds., 1997). 
perspectives sometimes cannot elucidate human behavior without heeding the lessons from other fields of research. They enable us to comprehend human actions in specific social contexts, thereby helping to "elucidate specific evolutionary hypotheses". ${ }^{61}$

For instance, some important insights into our relationships with the natural environment are provided in the burgeoning field of behavioral economics. It analyses human cognitive and emotional factors to understand economic decisions by consumers, investors, and other actors, as well as how they affect prices and allocation of resources. ${ }^{62}$ Behavioral economics has advanced more nuanced models of human behavior that reject the neoclassical view that humans are narrow, cost-benefit maximizing machines. ${ }^{63}$ Seminal advances include theories by Herbert Simon on "bounded rationality" ${ }^{64}$ and George Ainslie on "inter-temporal choices", 65 which together show that people make seemingly irrational decisions under the influence of a range of cognitive biases, and that the way an issue is "framed" to a decision maker will affect their action.

One illustration of how our "irrational" beliefs can have important consequences for environmental policy-making is the phenomenon known as the "endowment effect". An assumption of neoclassical rational choice theory is that people will value property logically and consistently. However, experiments show that people often value something they have just acquired more highly than they would have been willing to pay for it. ${ }^{66}$ Endowment effects can affect the allocation of and trade in property rights in market economies, because property owners may be unwilling to exchange their rights to others. The result could be an economically inefficient allocation of property entitlements, such as in a tradable emission allowances market. Endowment effects are also predicted by evolutionary psychology as a legacy of our efforts in ancestral environments to protect territorial possessions which required that we perceive them to be highly valuable. ${ }^{67}$

61 THE HANDBOOK OF EVOLUTIONARY PSYCHOLOGY 805 (David M. Buss ed., 2005).

62 See generally Matthew Rabin, Psychology and Economics, 36(1) J. ECON. LIT. 11 (1998).

63 Oliver Jean Blanchard, Neoclassical Synthesis, in NEW PALGRAVE: A DICTIONARY OF ECONOMICS (John Eatwell, Murray Milgate \& Peter Newman eds., 1987).

64 HERBERT SIMON, MODELS OF BOUNDED RATIONALITY, VOLS. 1 \& 2. (1982).

65 George Ainslie, Derivation of "Rational" Economic Behavior from Hyperbolic Discount Curves, 81 AM. ECON. REV. 134 (1991).

Mathew L. Spitzer \& Elizabeth Hoffman, Willingness-to-Pay versus Willingness-to-Accept: Legal and Economic Implications, 71 WASH. U. L. Q. 59 (1993) THEORY, Vol. 7, 17, 26 (Roger Koppl ed., 2004). 


\section{The Kinder Side of Human Nature: The Social Animal}

Mounting empirical research and new theoretical understandings also reveal that people have extensive cooperative and altruistic tendencies, and these understandings have important implications for the design of environmental law. ${ }^{68}$ Throughout human history we have increasingly coagulated socially. While the theory of natural selection posits that reproductive selfishness drives individual behavior, this traditional assumption has had to be modified to explain observations of seemingly "altruistic" behavior. Altruism can be defined as behavior directed toward the benefit of others at some cost to the giver. Humans across many cultures act in seemingly altruistic ways, even helping strangers whom they might never meet again. Such morality has been theorized as partly a product on an evolutionary heritage we share with other social mammals, especially for within-group morality based on kinship, reciprocity and empathy. ${ }^{69}$ Marc Hauser in his magnum opus, Moral Minds, argues that our capacity for morality is innate, like the capacity for language itself, honed by thousands of years of evolution rather than being a recent cultural construct. ${ }^{70}$ Dutch biologist Frans de Waal concludes that people "are moral beings to the core", ${ }^{71}$ who like a number of species including primates, elephants, and dolphins, have deeply evolved capacities to be cooperative and sensitive to injustice and peace-loving. ${ }^{72}$ Humans' capacity for reason, enabling people to abstractly and impartiality consider the welfare of others, outside of their group, is considered by ethicist Peter Singer as an additional basis for morality unlike other social mammals. ${ }^{73}$ The intellectual capacity for reasoning can underpin the development of human rights and environmental laws that provide for protection for interests seemingly remote to an individual's own interests.

While altruism might make sense when we recognize that human beings evolved for group living, the puzzle is why should an individual behave cooperatively when it appears costly to perform but benefits other persons? The various theoretical explanations of altruism include kinship, reciprocal altruism, indirect reciprocity or reputation, and commitment. In 1964 William Hamilton theorized that altruism serves individual reproductive advantage by passing

68 For a very useful discussion of the terminology, see S.A. WEST, A.S. GRIFFIN \& A. GARDNER, Social Semantics: Altruism, Cooperation, Mutualism, Strong Reciprocity and Group Selection, 20(2) J. EVOL. BIOLOGY 415 (2007).

69 FRANS DE WAAL, GOOD NATURED: THE ORIGINS OF RIGHT AND WRONG IN HUMANS AND OTHER ANIMALS 10, 12 (1996).

MARC D. HAUSER, MORAL MINDS: HOW NATURE DESIGNED OUR UNIVERSAL SENSE OF RIGHT AND WRONG xvii (2006). The problem however, explains Ronald Wright, is that while "human beings are a species splendid in their array of moral equipment", they are "tragic in their propensity to misuse it, and pathetic in their constitutional ignorance of the misuse": WRIGHT, supra note 5, at 13.

DE WAAL, supra note 69 , at 2.

See further FRANS DE WAAL, THE AGE OF EMPATHY: NATURE'S LESSONS FOR A KINDER SOCIETY (2009); FRANS DE WAAL, STEPHEN MACEDO \& JOSIAH OBER (EDS), PRIMATES AND PHILOSOPHERS: HOW MORALITY EVOLVED (2009).

PETER SINGER, THE EXPANDING CIRCLE: ETHICS AND SOCIOBIOLOGY 167-73 (1981). 
along not one's body but one's genes. ${ }^{74}$ Genetic selfishness, believed Hamilton, could make room for altruism; for example, by helping close relatives and improving their chances to reproduce, an individual is still passing on his or her own genes to the next generation, albeit indirectly. Thus, the extent to which an individual is willing to sacrifice for another should vary according to his or her degree of consanguinity. In 1971, Robert Trivers suggested that cooperation could also be favored between nonrelatives, through reciprocal interactions. He coined the term "reciprocal altruism" to describe helping behavior in the expectation of future reciprocation-an arrangement that thrives best among individuals with frequent interactions in stable social networks. ${ }^{75}$ Cooperative big game hunting and the sharing spoils of the kill was likely a seminal incubator of such practices. ${ }^{76}$ As others have since pointed out, such reciprocal interactions are better described as mutually beneficial arrangements rather than pure altruism. ${ }^{77}$ Reciprocal altruism can also be understood as reciprocal obligations, since giving favors to others "puts the recipient under an obligation to reciprocate". ${ }^{78}$ People perceived by their peers as stingy might compromise their social standing and welfare.

These ideas were elaborated by Richard Alexander's theory of "indirect reciprocity" to explain the development of moral systems in human societies, in which our social reputation drives individuals not only to assist the person to whom they owe something, but also to somebody else in society. ${ }^{79}$ Kristen Hawkes argues that the more valuable rewards of reciprocal altruism are often intangible, involving social recognition for one's sharing and public-spiritedness. ${ }^{80}$ In a further extension of the altruistic circle, Robert $\mathrm{H}$. Frank has argued that emotions such as love and trust can predispose people to act against their self-interest. ${ }^{81}$ Such emotions can foster social cooperation; for example, in situations depending on trust; from business deals to marriage, highly self-interested people often fare worse than those with an "irrational" loyalty to abstract ideas of fairness.

Other research has concentrated on the factors that nurtured these cooperative and altruistic tendencies. Harvard anthropologist, Richard Wrangham, argues that as a consequence of humans becoming more sedentary over the millennia, including cooking, eating together, and

74 William D. Hamilton, The Genetical Evolution of Social Behaviour, 7 J. THEORETICAL BIOLOGY 1 (1964).

75 Robert Trivers, The Evolution of Reciprocal Altruism, 46 Q. REV. BIOLOGY 35 (1971).

76 RIDLEY, supra note 28 , at 107-08.

77 WEST, GRIFFIN \& GARDNER, supra note 68 , at 420.

78 RIDLEY, supra note 28 , at 118.

RICHARD ALEXANDER, DARWINISM AND HUMAN AFFAIRS (1979).

Kristen Hawkes, Showing Off: Tests of an Hypothesis About Men's Foraging Goals, 12(1) ETHOLOGY \& SOCIOBIOLOGY 29 (1991); Kristen Hawkes, Sharing and Collective Action, in EVOLUTIONARY ECOLOGY AND HUMAN BEHAVIOR 269 (Eric A. Smith \& Bruce Winterhalder, eds., 1992). 
learning good table etiquette, there have been natural selection pressures for greater withingroup harmony. ${ }^{82}$ Sarah Hrdy's Mothers and Others pinpoints the human practice of alloparenting $^{83}$ as our most unique attribute compared to other primates that has fostered selective pressures that favor individuals who are better at empathizing and thus cooperating with others. ${ }^{84}$ Neurology research also shows how our emotional responses to others' suffering and intuitive ability to put oneself in another's shoes provide the natural foundations for human morality. Scientists have observed how the brain's mirror neurons respond similarly to pain in one patient and the observation of pain in another. ${ }^{85}$ Individuals' neuroactive hormone oxytocin levels have been identified as motivating their experience of empathy and trust. ${ }^{86}$ Perhaps, then, we are creatures so fundamentally social that we do not need the Lockean social contract to live together.

But while human moral capacity has a deep evolutionary lineage, our genes do not prescribe any specific moral rules. That is the work of culture, which can mould our natural propensities into more cooperative and altruistic environmental behavior. ${ }^{87}$ Cooperative living allowed humans to indulge in ecological strategies, such as group hunting of large animals, which would be impossible for solitary creatures. ${ }^{88}$ Meeting the environmental challenges we face today will surely require further evolution of cooperative norms. Cooperation within small, closely-knit hunter-gatherer bands is vastly different than addressing the collective action problems of getting nations around the world to work cooperatively to reduce carbon emissions, protect forests, and reduce unsustainable marine fishing. Our evolved tendencies to cooperate and be altruistic are strongest in local settings among closely related peers, and are at their weakest in larger-scale contexts involving many unrelated groups. Overcoming this problem of scale will require evolution of stronger cooperative norms. ${ }^{89}$

82 RICHARD WRANGHAM, CATCHING FIRE: HOW COOKING MADE US HUMAN $184-86$ (2009); see also PETER HAMMERSTEIN (ED.), GENETIC AND CULTURAL EVOLUTION OF COOPERATION (2003).

83 Alloparenting is the practice of youngsters being cared for by their extended family including aunts and grand-parents.

SARAH B. HRDY, MOTHERS AND OTHERS: THE EVOLUTIONARY ORIGINS OF MUTUAL UNDERSTANDING 175208 (2009); see also, as an example, Paula K. Ivey, Cooperative Reproduction in Ituri Forest Huntergatherers: Who Cares for Efe Infants? 41 CURRENT ANTHROP. 856 (2000).

MAKSIM STAMENOV \& VITTORIO GALLESE (EDS.), MIRROR NEURONS AND THE EVOLUTION OF BRAIN AND LANGUAGE (2002).

Paul J. Zak \& Ahlam Fakhar, Neuroactive Hormones and Interpersonal Trust: International Evidence, 4(3) ECON. \& HUMAN BIOL. 412 (2006). See ROBERT AXELROD, THE EVOLUTION OF COOPERATION (1984); Trivers, supra note 73. RIDLEY, supra note 28, 106.

Some researchers argue that human beings have evolved the capacity for large-prosociality, through interrelated cultural and genetic evolutionary tendencies. For example, social selection mechanisms such as exclusion from the marriage market, denial of the fruits of cooperative societies and ostracism can create strong selection against genes tending toward antisocial behaviour. Adrian V. Bell, Peter J. Richerson \& Richard McElreath, Culture Rather than Genes Provides Greater Scope for the Evolution of Large-scale Human Prosociality, 106(42) PROCEEDINGS NATIONAL ACADEMY OF SCIENCES 17671 (2009). 
Whether altruism is driven by genetic selfishness, tit-for-tat, or other self-serving motives, some commentators believe that what is ultimately important is whether it achieves results. As Matt Ridley illustrates, "If I am setting out to raise money for a charity, I am not going to return the cheques of companies and celebrities on the grounds that they are motivated more by the search for good publicity than by the cause itself". ${ }^{90}$ A similar debate about the potential tradeoff between means and ends sometimes arises in modern environmental policy. Environmentalists once vehemently opposed economic policy instruments such as emission taxes, on the basis that these were an unethical way to manage pollution. Allowing polluters to "buy" their right to pollute was viewed as trivializing a problem that required a more coercive response, such as strict regulatory sanctions to limit emissions. ${ }^{91}$ But, increasingly, environmental advocates view green taxes and other economic tools more pragmatically as useful tools to give market actors incentives to improve their behavior. ${ }^{92}$ In other words, environmentalists' focus has shifted from means to ends, where what matters is not so much how or why companies or individuals act so long as the desired change occurs expeditiously. Nonetheless, the foregoing points are certainly not reasons to ignore understanding why humans may act cooperatively or altruistically; effective policy tools must be designed to provide the appropriate incentives or reasons to act-what may motivate a person in one situation may not motivate another. In the case of pollution taxes levied on market actors such as corporations, the economic incentive can provide a compelling motivation for entities strongly imbued with a cost-benefit mentality.

Therefore, human environmental behavior functions within some evolved decision-making constraints. One of these constraints is that cooperation is more likely to occur among those who are close relatives or who previously have reciprocally shared resources. Cooperation is fostered when people believe in the probability of future reciprocation. People also tend to undervalue future costs and benefits, perhaps because of the more precarious and shorter lives humans endured in ancestral environments. This cognitive bias can affect the prospects for long-term decision making, such as to address climate change. People also have trouble understanding notions of probability and risk, depending on the format that risk information is framed in. But our evolved psychology does not by itself supply any normative guidance on how we should act towards the environment or what type of environmental laws we should adopt. What is natural is not necessarily moral. We cannot derive morals from facts, or "ought" from "is". But evolutionary theory can help law-makers by revealing policy conflicts, clarifying causal links and providing robust explanations for behavioral data lacking coherence.

$90 \quad$ RIDLEY, supra note 28 , at 21.

91 Robert N. Stavins, What Can We Learn from the Grand Policy Experiment? Lessons from SO2 Allowance Trading, 12(3) J. ECON. PERSPECTIVES 69, 72, 75-77 (1998).

92 Id. at 75-77. 
The cognitive biases and maladaptions recognized by evolutionary science can be theorized, explains Owen Jones, a law professor at Vanderbilt University, as a result of "time-shifted rationality"..$^{93}$ In other words, there is a "temporal mismatch between design features of the brain appropriate for ancestral environments, on one hand, and quite different current environments, on the other". ${ }^{94}$ What a cognitive defect is today was once an evolved adaptation to different environmental conditions. Thus, in modeling the "law of law's leverage", Jones predicts that: "The magnitude of legal intervention necessary to reduce or to increase the incidence of any human behavior will correlate positively or negatively, respectively, with the extent to which a predisposition contributing to that behavior was adaptive for its bearers, on average, in past environments". ${ }^{95}$ Behaviors that can be difficult to modify include those relating to control of property and territory, resource accumulation, risk valuation, and certain forms of altruistic behavior. While beliefs and traits deeply embedded in human evolutionary history are not necessarily impossible to change, they will likely generate greater resistance to legal influences and thus be more costly to change. Nonetheless, there may be some situations where behavior can be changed, without great cost, by using tools historically linked to traditional beliefs and decision rules, such as community shaming to affect an individual's status.

Having thus introduced the basic precepts of evolutionary psychology, I will now focus in more detail on how our evolutionary inheritance has shaped our beliefs and practices with regard to the natural environment.

\section{HUMANS' ENVIRONMENTAL RELATIONSHIPS}

\section{A. OUR EnVIronmental Burden in An EVolutionary ConteXt}

Environmental law, like other fields of law, is an expression of human culture. Biohistorians who study the evolutionary path of humankind, view the emergence of culture as not only humankind's most significant characteristic as a species, but also the factor that has made us the planet's dominant evolutionary force. ${ }^{96}$ It is not only the capacity to act culturally that makes humans unique-culture abounds in a number of highly intelligent mammals including chimpanzees and killer whales ${ }^{97}$-but also the capacity to accumulate culture and transmit ideas efficiently across generations. ${ }^{98}$ Human cultures are the knowledge and associated

93 Owen Jones, Time-Shifted Rationality and the Law of Law's Leverage, 95 NORTHWESTERN U. L. REV. 1141 (2001).

94

Owen D. Jones, Evolutionary Psychology and the Law, in THE HANDBOOK OF EVOLUTIONARY PSCYHOLOGY 953, 960 (David M. Buss ed., 2005).

Id. at 962 .

Stephen Palumbi, Humans as the World's Greatest Evolutionary Force, 239 SCIENCE (2001), 1786; CLIVE PONTING, A GREEN HISTORY OF THE WORLD: THE RISE AND FALL OF GREAT CIVILIZATIONS (1992).

See e.g., Andrew Whiten, Culture in Chimpanzees, 399 NATURE 682 (1999).

RIDLEY, supra note 60, at 209-10. 
behaviors, including language, technologies, arts, economic systems, and political organizations, that are transmitted socially. One of the most seminal characteristics of cultures is the behavioral rules we call "law" that govern its members' interactions with one another and their environment.

Culture has been a mixed blessing. On the one hand, it has spawned complex global cities, stupendous technological innovation and sophisticated legal institutions. On the other hand, it has also fostered some ideas and practices that are maladaptive, in the sense that they cause much unnecessary human distress, or undesirable damage to ecosystems, or both. These cultural maladaptions once included ancient customs such as burning witches at the stake and the foot-binding of young girls. Today, we have the misguided invention of weapons of mass destruction, the rapacious burning of fossil fuels, and the eating of endangered species in the dubious belief that they possess talismanic, medicinal properties. The persistence and pervasiveness of these and other cultural practices raises the issue of whether they are reflective of more deeply embedded characteristics of humankind. Beneath the global mosaic of diverse customs are some familiar and enduring patterns with regard to human preferences, emotions, cognition, and values. ${ }^{99}$

Can we shift to a more socially compassionate and environmentally sustainable path through further cultural change? Humans evolve culturally much more quickly than they change genetically. Although people to some extent adjust their behavior as circumstances require, and can accumulate inherited knowledge, this should not imply that individuals start as a blank slate, able to be molded culturally in any direction. Yet, many social psychologists (e.g., John B. Watson), ${ }^{100}$ sociologists (e.g., Emile Durkheim), ${ }^{101}$ and anthropologists (e.g., Margaret Mead) ${ }^{102}$ once thought human behavior was a result of the social environment alone, not by anything biological. In this vein, it has been concluded, "Humans, then, are tabula rasa-blank slates-upon which the imprint of their social environments is indelibly printed. [There are] certain innate drives, such as sex and hunger, but [they are] diffuse in form and few in number". ${ }^{103}$ Such extreme, socially deterministic views of human nature have now conceded to a growing recognition of the behavioral influence of the cognitive and psychological

\footnotetext{
99 ALAN S. MILLER \& SATOSHI KANAZAWA, WHY BEAUTIFUL PEOPLE HAVE MORE DAUGHTERS 1-8 (2007).

100 JOHN B. WATSON, BEHAVIOR: AN INTRODUCTION TO COMPARATIVE PSYCHOLOGY (1914).

101 EMILE DURKHEIM, RULES OF SOCIOLOGICAL METHOD 106 (1966) (contending that "Individual natures are merely the indeterminate material which the social factor determines and transforms").

102 MARGARET MEAD, COMING OF AGE IN SAMOA: A PSYCHOLOGICAL STUDY OF PRIMITIVE YOUTH FOR WESTERN CIVILIZATION (1928).

103 ROBERT F. MURPHY, CULTURAL AND SOCIAL ANTHROPOLOGY: AN OVERTURE 15 (3rd. edn., 1989).
} 
characteristics built into the evolved human brain. ${ }^{104}$ In other words, cultural change occurs within certain biological parameters.

The biological basis to our behavior may thus help to validate research that suggests that well before the cultural innovations of the last few millennia humans perpetrated much environmental harm. ${ }^{105}$ The evidence, however, is not all one-sided. Our distant past hints at humankind's capacity for environmental sensitivity. William Burroughs surmises that it came "from watching movements of migratory birds, which are very sensitive to climatic shifts" and "observing the timing of the different stages of vegetation". ${ }^{106}$ This supposed empathy for animals dates to the hunter-gatherer stage of human evolution when it was a matter of sheer survival that people be able to "interpret and anticipate the behavior of animals". ${ }^{107}$ Burroughs cites the vivid depictions of animals in the 15,000 year-old paintings in the Lascoux caves of southern France as evidence of our awe and appreciation of nature. ${ }^{108}$ The transition from hunter-gatherer to agricultural lifestyles, which included the domestication of some species to serve as companions, may have perpetuated aspects of this tendency. ${ }^{109}$

Incongruously, however, during these same periods humans were also simplifying ecosystems and eliminating many species, as well as fighting among themselves for control of territory and natural resources. Archaeological evidence from several Paleolithic sites in North Africa and Europe has unearthed mass graves in which projectile points are embedded in skeletons and skulls once splintered by stone axes. ${ }^{110}$ Concomitantly, there is evidence that large, ungainly animals and birds in areas unaccustomed to the presence of humans were decimated by the first hunters. The arrival of the Clovis people in North America some 11,000 years ago and the Māori in New Zealand 1,000 years ago appears to have led swiftly to the demise of the mega

104 See ROBERT A. BARON \& DONN BRYNE, SOCIAL PSYCHOLOGY 12 (2000); STEVEN PINKER, THE BLANK SLATE: THE MODERN DENIAL OF HUMAN NATURE (2002). There is also recognition of biological factors directly shaping cultural change: TIMOTHY H. GOLDSMITH \& WILLIAM F. ZIMMERMAN, BIOLOGY, EVOLUTION AND HUMAN NATURE 317 (2001).

Rees argues that "sustainability requires that we acknowledge the primitive origins of human ecological dysfunction". William Rees, Globalization and Sustainability: Conflict or Convergence? 22(4) BULL. SCI. TECH. \& SOC. 249, 249 (2002). The debate continues with regard to those human communities-indigenous peoples-seen as the closest model to our primitive ancestors: Lisa Shields, Are Conservation Goals and Aboriginal Rights Incompatible?, 10 J. ENVTL L. \& PRAC. 187 (2000); Allyn Stearman, Revisiting the Myth of the Ecologically Noble Savage in Amazonia: Implications for Indigenous Land Rights, 49 CULTURE \& AGRICULTURE 2 (1994).

WILLIAM BURROUGHS, CLIMATE CHANGE IN PREHISTORY: THE END OF THE REIGN OF CHAOS 163-64 (2005).

Id., at 162 .

108 Id., at 161-62.

109 Id., at 165.

110

TIMOTHY H. GOLDSMITH \& WILLIAM F. ZIMMERMAN, BIOLOGY, EVOLUTION AND HUMAN NATURE 340 (2001). 
fauna, notably the mammoths ${ }^{111}$ and moas respectively in these lands. ${ }^{112}$ The new arrivals might have lacked awareness of the relative scarcity of unfamiliar natural resources and may not have evolved the requisite social norms quickly enough to limit exploitation of a declining resource. ${ }^{113}$

The spread of agriculture wrought even more extensive environmental changes. Vast areas of Western Europe and Southeast Asia became deforested. ${ }^{114}$ William Ruddiman attributes the increase in atmospheric carbon dioxide and methane at 8,000 and 5,000 years ago respectively, as verified in ice-core samples, to forest clearance, intensive rice cultivation and other landscape changes. ${ }^{115}$ The growth of farming also ushered in the first great urban civilizations in the Levant and other regions, thereby even more profoundly distancing humankind from the natural world. ${ }^{116}$ Eventually, some of these environmental upheavals likely precipitated the decline or collapse of entire civilizations-such was the fate of the Maya civilization in Central America. ${ }^{117}$

In the very distant past, in a world with few people and Stone Age technologies, humankind could probably act without much concern for ecological constraints. But some behaviors that were functional in ancestral environments have become irrational and maladaptive today under different conditions, when we number billions and are equipped with destructive technologies. Such evolutionary time lags arise because evolution happens slowly, usually over thousands of generations, so that existing humans remain a legacy of the environments they

111 In North America, Clovis hunters likely had a major hand in the demise of some 35 primarily large mammals, including mammoths. See Leigh Dayton, Mass Extinctions Pinned on Ice Age Hunters, 292 SCIENCE 1819 (2001). The evidence of such impacts is disputed by some: e.g., Donald Grayson \& David Meltzer, Clovis Hunting and Large Mammal Extinction: A Critical Review of the Evidence, $16 \mathrm{~J}$. WORLD PREHISTORY 313 (2002).

112 Flannery, an Australian scientist who has documented such ecological changes, describes the arrival of Māori hunters as precipitating a "blitzkrieg extinction" in which some 12 species of moa (giant birds, most larger than ostriches) were exterminated within a few centuries: FLANNERY, supra note 10, at 195

See further ROBERT EDGERTON, SICK SOCIETIES: CHALLENGING THE MYTH OF PRIMITIVE HARMONY (1992); TIM FLANNERY, THE ETERNAL FRONTIER (2001).

Frank Oldfield, The Role of People in the Holocene, in NATURAL CLIMATE VARIABILITY AND GLOBAL WARMING: A HOLOCENE PERSPECTIVE 58, 64 (Richard W. Battarbee \& Heather A. Binney eds., 2008); Bernard Maloney, Pollen Analytical Evidence for Early Forest Clearance in North Sumatra, 287 NATURE 324 (1980).

William F. Ruddiman, The Anthropogenic Greenhouse Era Began Thousands of Years Ago, 61 CLIMATIC CHANGE 261 (2003).

GRAEME BARKER, THE AGRICULTURAL REVOLUTION IN PREHISTORY: WHY DID FORAGERS BECOME FARMERS? 1-2 (2006). 
inhabited long ago. Evolutionary time lags lead to a phenomenon which Owen Jones describes, as previously noted, as "time-shifted rationality". ${ }^{118}$

Such mismatches in our psychological adaptation can have serious environmental and social consequences. One example is our strong taste for fatty foods. Historically our preference for fat was highly adaptive, because it was a valuable and scarce source of concentrated calories. But in today's era of relatively cheap food, fat is available in vast quantities. Our continuing preference for it has caused us to indulge, and thus incur numerous health problems associated with obesity. ${ }^{119}$ Our environmental maladaptions, as examined in the next section, pose even greater risks to our long-term well-being.

\section{B. EnVironmental Behavioral Maladaptions}

Most relevant for environmental law-making, many of the behavioural traits identified by evolutionary psychologists are manifested around issues of cooperation and conflict. Behavioral scientists, like political philosophers, have spilt an extraordinary amount of ink debating the competitive, cooperative, or altruistic impulses of people. It is evident from the titles of polemics such as Biological Constraints on the Human Spirit, ${ }^{120}$ Why We Are the Way We Are, ${ }^{121}$ How Morality Evolved, ${ }^{122}$ and The Modern Denial of Human Nature. ${ }^{123}$ Because evolutionary biologists stress that competition among individuals is essential to the process of natural selection, many believe that individuals "have no natural moral tendency to extended altruism" beyond their close kin, ${ }^{124}$ with every instance of altruistic behavior being just a disguised form of self-interest. While we are an intensely social species that seeks company and inclusion, our biology predisposes us to intimate groups of usually no more, and often fewer, than 150 individuals. Our evolved sociable and altruistic tendencies seem to flourish best in small communities of kin-related individuals, a relic of our hunter-gatherer history, and wane in more diffused and distant relationships among strangers. Yet much environmental governance, especially at an international level, requires high levels of social cooperation in the latter situation. Addressing climate change and managing ocean fisheries are two pressing examples. ${ }^{125}$

118 Owen D. Jones, Time-Shifted Rationality and the Law of Law's Leverage, 95 NORTHWESTERN U. L. REV. 1141, 1173 (2001).

119

120

121

123

124

DAVID M. BUSS, EVOLUTIONARY PSYCHOLOGY: THE NEW SCIENCE OF THE MIND 52 (2004).

MELVIN KONNER, BIOLOGICAL CONSTRAINTS ON THE HUMAN SPIRIT (2002).

RONALD WRIGHT, MORAL ANIMAL: WHY WE ARE, THE WAY WE ARE. NEW SCIENCE OF EVOLUTIONARY PSYCHOLOGY (1994).

FRANS DE WAAL, PRIMATES AND PHILOSOPHERS: HOW MORALITY EVOLVED (2006).

PINKER, supra note 104.

William E. Rees, Past the Tipping Point? The Coming Post-Sustainability World, Global Ecological Integrity Group Conference (Samos, Greece, July 4-9, 2006).

See URS LUTERBACHER \& DETLEF F. SPRINZ EDS, INTERNATIONAL RELATIONS AND GLOBAL CLIMATE CHANGE (2001); James A. Wilson, Matching Social and Ecological Systems in Complex Ocean Fisheries, 11(1) ECOL. \& SOC. 9 (2006). 
While a competitive instinct can be harnessed as a powerful motivation to find solutions to some environmental problems, for example, by stimulating technological and entrepreneurial innovations in the market-place, the propensity of people to splinter into competing groups has left us with minds prone to adopt prejudices, feud violently, and pursue selfish ends at the expense of everyone's long-term interests. For Murray Bookchin, the human domination and exploitation of nature is largely a consequence of how we tend to treat one another. ${ }^{126}$ It is thus not surprising that the so-called "deep ecologists" often stress the importance of developing egalitarian and cooperative means of environmental decision making. ${ }^{127}$

Another environmentally-relevant behavioral disposition relates to how people value the future. It is sometimes said that one of the most foremost attributes of human beings, which makes us unique among species, is that "humans alone are capable of recognizing the threat posed by their own natural propensities". ${ }^{128}$ Seemingly, we can anticipate and plan for a better future. Environmental law itself is one manifestation of this tendency, evident by the precautionary principle which informs many standards and procedures, such as environmental impact assessment and land use planning, that encourage cautious decision making. ${ }^{129}$ Examples of this tendency in other spheres of modern life include investment schemes such as pension plans which help ensure that one does not retire destitute, and insurance markets which enable individuals to hedge against the risk of costly accidents and misfortune.

Yet, in many other situations people evidently act as though there is no tomorrow. Despite unprecedented advances in environmental science in recent decades, humankind often acts obliviously to its lessons. Partly, this is due to the more diffused nature of many contemporary environmental problems, such as climate change, which are difficult to grasp conceptually. Thus, as Rolf Lidskog puts it, "these threats are becoming more remote from our perceptual apparatus and acquiring form as abstract prognoses that are beyond lay people's knowledge and experience" ${ }^{130}$ Most societies worldwide have shown themselves to be not particularly proactive in dealing with environmental problems of a long-term nature. Instead, the gravity of any threats is denied or trivialized until they materialize to the point of demonstrably

126 MURRAY BOOKCHIN, THE ECOLOGY OF FREEDOM: THE EMERGENCE AND DISSOLUTION OF HIERARCHY (1982).

127 Ben Boer, Social Ecology and Environmental Law, 1(3) ENVTL \& PLAN. L.J. 233 (1984).

128

James A. Karr, attaining a Sustainable Society, in ReCONCILING hUMAN eXISTENCE With eCOlOGiCal INTEGRITY 1, 24 (LAURA WESTRA, KLAUS BOSSELMANN \& RICHARD WeSTRA EDS., 2008).

129 See generally PERSPECTIVES ON THE PRECAUTIONARY PRINCIPLE (Ronnie Harding \& Elizabeth Fisher eds., 1999); WALTER E. WESTMAN, ECOLOGY, IMPACT ASSESSMENT, AND ENVIRONMENTAL PLANNING (1985).

130 Rolf Lidskog, Scientific Evidence or Lay People's Experience: On Risk and Trust with Regard to Modern Environmental Threats, in RISK IN THE MODERN AGE: SOCIAL THEORY, SCIENCE, AND ENVIRONMENTAL DECISION-MAKING 196, 202 (Maurice J. Cohen ed., 2000) 
interfering with our self-interest, such as when they engender diseases, droughts, and other impacts that overtly harm personal health or economic prosperity.

Behavioral economics research also shows that people tend not to apply rationally appropriate "discount rates" when evaluating the future. We often rely on ridiculously high discount rates, thus weighing present costs and benefits too highly in comparison to future costs and benefits. ${ }^{131}$ The tendency to discount the future heavily might once have been a rational bias for people in ancestral environments, but under today's conditions it is inappropriate. Such conditions include that people on average live much longer lives-the emergence of a more reliable future which enables people to reap the benefits of deferred gratification-and economic mechanisms such as currencies and pensions which enable future wealth to be conveniently stored. ${ }^{132}$ But our lingering propensity to discount the future can exacerbate our lame reaction to some environmental problems, such as discouraging pollution abatement despite the high long-term advantages of acting now on our prescience, and failing to intervene to protect threatened species until they become critically endangered. ${ }^{133}$

By the same mismatching process, people tend not to have evolved the requisite fears of some environmental dangers to themselves and posterity. We have an intensely evolved fear of spiders, snakes, sharks, and tigers, ${ }^{134}$ as well as a fear of heights and darkness, ${ }^{135}$ but seemingly lack a similar instinctive wariness about pollution and other insidious environmental threats posed by modern life. Some scientists explain that irrational behavior, such as burning fossil fuels in the face of catastrophic climate change, is rooted in a universal human tendency of denial or self-deception. ${ }^{136}$ Living in denial of known environmental threats and impacts allows people to indulge in profligacy without being bothered by the need to take responsibility for nature's well-being. Such self-deceiving attitudes are evident even with regard to much more overt risks, such as living in areas prone to natural disasters ${ }^{137}$ or reckless investments in speculative markets. ${ }^{138}$

131 Daniel A. Farber \& Paul A. Hemmersbaugh, The Shadow of the Future: Discount Rates, Later Generations, and the Environment, 6 VAND. L. REV. 267 (1993).

132

133

Jones, supra note 93, at 960.

See Amy W. Ando, Waiting to be Protected under the Endangered Species Act: The Political Economy of Regulatory Delay, 42(1) J. L. \& ECON. 29 (1999); John P. Dwyer, Richard R.W. Brooks \& Alan C. Marco, The Political and Legal Causes of Regulatory Delay in the United States: Four Case Studies of Air Pollution Permitting in the U.S. and Germany, University of California at Berkeley Public Law and Legal Theory Working Paper No. 99-2 (1999).

Of the ingrained human fear of some predators, see DAVID QUAMMEN, MONSTER OF GOD: THE MANEATING PREDATOR IN THE JUNGLES OF HISTORY AND THE MIND (2004).

JEFFREY A. GRAY, THE PSYCHOLOGY OF FEAR AND STRESS 11-12 (1987).

DANIEL GOLEMAN, VITAL LIES, SIMPLE TRUTHS: THE PSYCHOLOGY OF SELF-DECEPTION (1996); Robert L. Trivers, The Elements of a Scientific Theory of Self-deception, 907 ANNALS N.Y. ACAD. SCI. 114 (2000).

Diane Roberts, Hurricanes in Florida: Living in Denial, National Public Radio (Aug. 22, 2004).

Brendan McSweeney \& Royal Holloway, Is Denial of the Possibility of Financial Asset Market Failure Responsible for an Economic Holocaust? (2009), available at http://www.rhul.ac.uk/Management/News- 
These attitudes are related to a cognate tendency to having an overly confident view of human progress. Current research in the field of psychology suggests strongly that people are often overly-optimistic. $^{139}$ For example, individuals tend to have unrealistically positive images of themselves, particularly when comparing themselves to others, which is described in the literature as the "better-than-average" effect. ${ }^{140}$ Being unrealistically optimistic however can lead individuals to make inaccurate and sometimes costly predictions. ${ }^{141}$ This cognitive bias in risk perception is not only due to a failure to appreciate the nature of specific harms, but also because we can fail to interpret the magnitude of risk. This problem apparently owes to how risk information is sometimes presented. For instance, many people have been found not to appreciate that a 0.5 risk of an accident is more hazardous than an activity in which 4 out of 10 people, or 40 percent, of actors will be hurt. ${ }^{142}$ Such cognitive biases resulting from how risk information is presented could presumably also affect the design of environmental laws designed to manage pollution and other toxic risks.

As for what evolutionary purpose could be served by how we misperceive risks and situations, Robert Trivers, an American evolutionary biologist, suggests "that there are intrinsic benefits to having ... a more optimistic view of the future than the facts would seem to justify" ${ }^{143}$ As Edward O. Wilson explains, this is probably because "[w]ithout it the mind, imprisoned by fatalism, would slow and deteriorate". ${ }^{144}$ Having a pessimistic outlook on life would in evolutionary terms lead people to forego opportunities because of a fear of failure. Taking risks, in other words, can be biologically adaptive.

Unfortunately, while some illusions about future prospects might have once been an evolutionary advantage, presently they are problematic for humankind. Pratarelli and Aragon surmise that perhaps only "environmental pressures in the form of imminent catastrophic ecological and/or economic collapse on a scale not seen in recorded human history are likely to

and-Events/News/2009/Brendan_McSweeney_Financial_Asset Market_Failure.pdf (last visited August 28, 2010).

John R. Chambers, Paul D. Windschitl \& Jerry Suls, Egocentrism, Event Frequency and Comparative Optimism: When What Happens Frequently is "More Likely to Happen to Me", 29(11) J. PERSONALITY \& SOC. PSYCH. BULL. 1343 (2003).

Mark D. Alicke, et al., Personal Contact, Individuation, and the Better-than-Average Effect, 68(5) J. PERSONALITY \& SOC. PSYCH. 804 (1995).

David Armor \& Aaron Sackett, Accuracy, Error and Bias in Predictions for Real Versus Hypothetical Events, 91(4) J. PERSONALITY \& SOC. PSYCH. 583 (2006).

Paul Slovic, Baruch Flischhoff \& Sarah Lichenstein, Facts Versus Fears: Understanding Perceived Risk, in JUDGMENT UNDER UNCERTAINTY: HEURISTICS AND BIASES 463 (Daniel Kahneman, Paul Slovic \& Amos Tversky eds., 1982). 
compel humans to adapt their value systems to focus on conservation practices and sustainable economic policies". ${ }^{145}$ Crises sometimes can trigger major structural reform, such as when the Great Depression of the 1930s motivated sweeping economic policy changes in many countries. The problem is that most environmental problems and threats, such as climate change, are catastrophes in relative slow motion; although in geological time their emergence and impact can be exceptionally rapid, they remain perceptibly rather long-term for humankind. Only episodic natural disasters seem to be able to sometimes trigger more immediate responses.

Stephen Boyden, an Australian biohistorian, concludes that these evolved propensities to fear ancestral dangers but not modern perils, as well as other psychological environmental maladaptions, are a result of the widening dissonance between humans' slow biological evolution and rapid cultural advance. ${ }^{146}$ Essentially, an ancient instinctive drive to acquire and consume resources for survival-an "inherent and essential element of all biological systems operating under natural selection pressures" ${ }^{147}$-has become a maladaptive tendency for a species that now numbers nearly seven billion and is equipped with dangerous technologies. ${ }^{148}$ Boyden labels these mismatching tendencies as "eco-deviation". ${ }^{149}$

Is humankind therefore doomed by its evolutionary inheritance to mindlessly destroy its environment and thus itself? And, if so, what purpose could environmental law serve other than to forestall our day of reckoning? While human history since the Holocene began has generally been accompanied by significant environmental degradation, the evolutionary sciences also suggest that people have traits that could be harnessed to help shape a more sustainable future. We are not behaviorally one-dimensional and human evolutionary success also owes to our capacity for compassion, conscience, and cooperation. There are also substantial reasons to protect nature for our own survival and prosperity. The next Part examines this perspective in order to understand the opportunities for building a more effective system of environmental law.

145 Marc E. Pratarelli \& Connie M. Aragon, Acknowledging the "Primitive Origins of Human Ecological Dysfunction": A View Toward Efficacy and Global Ecological Integrity, GLOBALISATION (2008): available at http://globalization.icaap.org/currentissue.php (last visited August 20, 2010).

146 STEPHEN BOYDEN, WESTERN CIVILIZATION IN BIOLOGICAL PERSPECTIVE: PATTERNS IN BIOHISTORY 264-65 (1987); see also JOHN A. LIVINGSTON, ROGUE PRIMATE: AN EXPLORATION OF HUMAN DOMESTICATION (1994).

147 Pratarelli \& Aragon, supra note 145.

148 See MARC E. PRATARELLI, NICHE BANDITS: WHY BIG BRAINS CONSUMED AN ECOSYSTEM (2003).

149 BOYDEN, supra note 146, at 264. 


\section{REDESIGNING ENVIRONMENTAL LAW}

\section{A. Changing Human Environmental Behavior}

In order to avoid further environmental degradation, humanity will need more than cleaner technologies and less wasteful methods of using energy and other natural resources. Already we have at our disposal a plethora of technologies and solutions that could enable us to reduce considerably our ecological foot-print with only modest effort. ${ }^{150}$ Opinion polls over the years also show that a substantial majority of persons surveyed declare to be concerned about the environment. ${ }^{151}$ Yet, a vast chasm between rhetoric and action often persists. ${ }^{152}$ While minor behavioral changes have occurred in response to environmental pressures (e.g., gasoline price hikes can curb driving habits and increase demand for more fuel-efficient cars), these changes have tended to be too fleeting, superficial, or localized in making a difference. ${ }^{153}$

Given the bleak environmental prognosis and necessity to act urgently, human behavioral changes must arise culturally rather than by any biological process. ${ }^{154}$ In a sense, a rapid

150 Amory Lovins \& Chris Lotspeich, Fueling the 21st Century: The New Economy of Energy, 53 J. INT'L AFFAIRS 191 (1999).

151

See, e.g., Thomas Arcury, Environmental Attitude and Environmental Knowledge, 49 HUMAN ORG. 300 (1999); Daniel Krause, Environmental Consciousness: An Empirical Study, 25 ENVT \& BEHAVIOR 126 (1993); Riley E. Dunlap, Trends in Public Opinion Toward Environmental Issues: 1965-1990, in AMERICAN ENVIRONMENTALISM: THE U.S. ENVIRONMENTAL MOVEMENT 1970-1990 89 (Riley E. Dunlap \& Angela G. Mertig, eds., 1992); Yael Wolinsky-Nahmias \& So Young Kim, International Public Opinion on the Environment: Responses to Inequality and Globalization, ISPP 31st Annual Scientific Meeting, Paris, France (July 9, 2008), available at http://www.allacademic.com/meta/p245425_index.html.

Stewart Barr, Are We All Environmentalists Now? Rhetoric and Reality in Environmental Action, 35(2) GEOFORUM 231 (2005).

On the magnitude of changes needed to human environmental impacts, see generally DONELLA H. MEADOWS, DENNIS L. MEADOWS \& JORGEN RANDERS, BEYOND THE LIMITS: CONFRONTING GLOBAL COLLAPSE, ENVISIONING A SUSTAINABLE FUTURE (1992); William E. Rees, Ecological Footprint, Concept Of, in ENCYCLOPEDIA OF BIODIVERSITY 229 (S. Levin ed., 2001).

Biological-based change would be too slow to shift humans' environmental behavior. While behavioral adaptations are known to occur relatively "quickly" in other species, the time-frames are far too long for our circumstances. Dogs, for example, which diverged from wolves only over the last 15,000 years, adapted different behaviors primarily through domestication; dogs under understand pointing gestures and making eye contact, whereas wolves do not. Johan De Smedt, Helen De Cruz \& Johan Braeckman, Why the Human Brain is Not an Enlarged Chimpanzee Brain, in HUMAN CHARACTERISTICS: EVOLUTIONARY PERSPECTIVES ON HUMAN MIND AND KIND 168, 170 (Henrik Hogh-Olesen, Jan Tonnesvang \& Preben Bertelsen eds., 2009). But curiously, some scholars believe that human biology is changing much more rapidly than traditionally assumed. American scientists Gregory Cochran and Henry Harpending in their best-seller, THE 10,000 YEAR EXPLOSION: HOW CIVILIZATION ACCELERATED HUMAN EVOLUTION (2007), dispute the received wisdom that Homo homo sapiens have reached an evolutionary plateau. One example they give is that among people of northern European descent, lactose intolerance-the inability to digest milk in 
mutation in cultural evolution must occur to trigger much more environmentally responsible attitudes and practices. Maladaptive cultural traits, like disadvantageous genetic mutations, could be "selected out" under congenial circumstances. Indeed, the historical record shows that some societies have occasionally dramatically shifted their moral sensibility, for example, through the abolition of slavery, ${ }^{155}$ the rise of the animal welfare movement ${ }^{156}$ and, most recently, the greatly improved status of women in some countries. ${ }^{157}$ Racism and sexism may certainly continue, even in the most enlightened countries, but they are much less publicly tolerated. Variations in societies' cultural trajectories also highlight that behaviorally humankind is not one-dimensional; indeed, scientists have even identified small genetic differences behind some of the world's diverse cultural memes. ${ }^{158}$ Societies differ in their environmental customs and impacts, depending on their technologies, economic systems, geographical circumstances, and many other variables. The high environmental burden of Western lifestyles, which has been traced as far back as the Christian-Judeo scriptures, ${ }^{159}$ can be contrasted to those aboriginal communities following frugal and subsistence livelihoods. ${ }^{160}$

Law can be an important tool for altering human behavior and directing cultural change. The tensions between the selfish inclinations of individuals and the requirements of group living, explain Richard Alexander, have fostered the development of moral systems that manifest

adulthood-is unusual today. But it was universal among humans before a genetic mutation about 8,000 years ago. Cochran and Harpending contend that our dynamic social and physical environments (including massive population increase, urbanization, and the dispersal and migration of people worldwide) are accelerating genetic mutations roughly 100 times faster than the overall average for the six million years of our hominoid lineage. Small genetic distinctions can have significant consequences, when you consider that human beings and chimpanzees share about 98 percent of the same genetic makeup: JONATHAN MARKS, WHAT IT MEANS TO BE 98\% CHIMPANZEE: APES, PEOPLE, AND THEIR GENES (2002). See generally SEYMOUR DRESCHER, ABOLITION: A HISTORY OF SLAVERY AND ANTI-SLAVERY (2009).

See generally KATHYRN SHEVELOW, FOR THE LOVE OF ANIMALS: THE RISE OF THE ANIMAL PROTECTION MOVEMENT (2008).

See generally KATHLEEN C. BERKELEY, THE WOMEN'S LIBERATION MOVEMENT IN AMERICA (1999).

For instance, most individuals in societies having a relatively "collectivist" culture, such as those in East Asia, have a specific mutation within a gene regulating the transport of serotonin, which is a neurochemical known to strongly affect mood. Eighty percent of them have the so-called " $\mathrm{S}$ " allele, which is strongly linked to negative emotions and an impulse to avoid risky behaviour. But in Western Europe and North America, where individual self-expression over group goals is often prized, the "L" allele dominates, with only 40 percent of Europeans carrying the " $\mathrm{S}$ " variant: Joan Y. Chiao \& Katherine D. Blizinsky, Culture-Gene Coevolution of Individualism-Collectivism and the Serotonin Transporter Gene, 28 PROCEEDINGS ROYAL SOCIETY B: BIOLOGICAL SCIENCES (2009), available at http://rspb.royalsocietypublishing.org/content/firstcite.

These scriptures include the Book of Genesis' directive to "subdue" the earth and to "have dominion over the fish of the sea and over the birds of the air and over every living thing that moves upon the earth". Lynn White, The Historical Roots of Our Ecological Crisis, 155 SCIENCE 1203, 1205 (1967), (referring to 1 Genesis 1:28).

See JULIAN T. INGLIS (ED.), TRADITIONAL ECOLOGICAL KNOWLEDGE: CONCEPTS AND CASES (1993); ROBERT JOHANNES (ED.), TRADITIONAL ECOLOGICAL KNOWLEDGE: A COLLECTION OF ESSAYS (1989). 
themselves in various ways, such as through legal rules and religious scriptures. ${ }^{161}$ Law is a tool that helps direct humans to behave in ways they otherwise would not, if left to their own devices. It works to modify aspects of the human environment in order to modify human behavior. But at the same time, long-standing scholarly debates about whether law leads or lags social change suggest that the law cannot rely on methods or goals that are fundamentally at odds with human nature if it is to be behaviorally effective. ${ }^{162}$ Both genetic dispositions and cultural learning shape human behaviour, and having more accurate behavioral models that incorporate understanding of such factors can improve the law's effectiveness.

With respect to social cooperation, law has often assumed a Hobbesian model of human interaction, in which legal intervention is considered to be indispensable for cooperation to flourish. ${ }^{163}$ The insights of evolutionary theory discussed in this article cast doubt on this assumption. Social cooperation is an indelible attribute of the human condition. While evolutionary psychology helps to explain the persistence of norms that evolved in ancient small group settings to modern large-scale society, by predicting that behavioural adaptations to ancestral environments will be "sticky" relative to changes in the social environment, many of our evolved instincts also leave us unsuited for modern life. These instincts must thus be suppressed or controlled by law and other institutions in order to promote economic prosperity and social welfare. The legal system can thus extend the sphere of cooperation for humans than would otherwise be naturally attainable. Law can promote cooperation both by enacting rules that direct human behavior towards specific policy goals and by creating organizations such as corporations or states that provide decision-making regimes for coordinating and managing human activities. For example, corporations, as artificial legal personalities, have profoundly shaped human economic activity including exploitation of nature for over two centuries. ${ }^{164}$ Human behavior in modern societies is thus not unleashed in some raw and unadulterated form, but, rather, is modulated through institutional and organizational settings which can stimulate and direct individuals' behavior in myriad ways.

Modern environmental law in Western countries has nearly half a century of experience in regulating natural resources exploitation, controlling pollution emissions, protecting biodiversity, and many other purposes. But its relative lack of success warrants new principles and methods. Environmental laws that are ineffective-because they are inattentive to the behavioral drivers of the actors they seek to influence-should be amended or repealed. Some of our most sophisticated legal mechanisms rest upon fictional and erroneous assumptions

161 RICHARD ALEXANDER, DARWINISM AND HUMAN AFFAIRS 219ff (1979).

162 See e.g., the "Law and Development" movement, which has debated the role of law as a means of leveraging economic and social change: DAVID M. TRUBEK \& ALVARO SANTOS (EDS.), THE NEW LAW AND ECONOMIC DEVELOPMENT: A CRITICAL APPRAISAL (2006). See further Jones, supra note 93. 
about human behavior. Concurrently, modern environmental law is increasingly blinded by ideological palliatives such as "sustainable development" that help us rationalize our continuing encroachments upon the planet. ${ }^{165}$ Better principles to guide the redesign of our environmental decrees and standards are necessary. We need to understand the degree to which humans carry various behavioral predispositions, and thereby to determine which institutions and regulations can suppress, modify, or channel these predilections toward environmentally sustainable behavior.

The challenge of making such regulation more behaviorally effective is also generating pertinent research from other academic disciplines including social psychology and behavioral economics. Canadian scholar Robert Gifford argues that climate change policy-makers should pay more attention to the psychology of individuals in finding ways to motivate change-for instance, by framing messages in positive terms, such that you can be part of a heroic vanguard of change, rather than by preaching to people to make costly sacrifices. ${ }^{166}$ Among behavioral economists, Richard Thaler and Cass Sunstein argue that individuals' choices are subtly influenced by the setting in which they make decisions, so that people rarely make "free" choices in an unadulterated milieu. ${ }^{167}$ The authors suggest that government policy-makers can paternalistically "nudge" individuals to make behavioral changes by simply rearranging that "choice architecture" without dictating or prescribing change. For example, more people are likely to comply with a practice voluntarily if they must actively opt-out of the practice rather than be asked to opt-in.

These and other insights are important in exposing the limitations of environmental regulation and how it might be reformed. To give one common example of environmental law's failings, pollution control legislation depends upon toxic substances or pollutants being released into the environment consistently with the product labeling or emission license approved by the regulator. ${ }^{168}$ Such regimes rely, in turn, upon meticulous adherence to a chain of controls, beginning with policy-makers setting environmental standards in accordance with robust scientific research into the effects of releases, efficient transmission of standards by regulators to polluters, studious attention to operational detail by the polluters, and subsequent diligent monitoring by enforcement personnel. This concatenation of steps can severely challenge human psychology. Not surprisingly, empirical research confirms that the improbable behavioral expectations of such pollution laws often do not occur, with environmental damage

165 See, e.g., John C. Dernbach, Sustainable Development as a Framework for National Governance, 49 CASE WEST. RES. L. REV. 1 (1998).

166 Robert Gifford, Psychology's Essential Role in Alleviating the Impacts of Climate Change, 49(4) CANADIAN PSYCH. 273 (2008). RICHARD H. THALER \& CASS SUNSTEIN, NUDGE IMPROVING DECISIONS ABOUT HEALTH, WEALTH, AND HAPPINESS (2008). 
resulting. ${ }^{169}$ Moreover, modern pollution regulations do not appear to be strongly facilitated by the civilizing influences of kinship, reciprocity, reputation, or other factors identified by the evolutionary theories of altruism. In most cases, the typical pollution episode creates risks to others (often non-humans) that are distant in time and place.

Law-makers should thus be wary of assuming that their commands alone can engender unmitigated altruistic behavior for the benefit of strangers or other species, and they should be smart in harnessing the altruistic and cooperative tendencies associated with kinship, reciprocity, reputation (which can be influential in a local community), and commitment or passion (which needs some proximity between people). While individuals in close communities have been shown to be able to solve problems of natural resource management by spontaneous mechanisms of ordering without the necessity of formal legal rules, ${ }^{170}$ strong evidence is lacking that humankind has an intrinsic conservation ethic to support environmental decision making in other contexts without the regulatory function of law. ${ }^{171}$ Environmental policies such as mitigating climate change or conserving biological diversity, which rely on only generalized and diffuse group benefits, risk failure. While (environmental) moralizing is certainly part of our evolved human character, obeying our call to be good is evidently not a particularly strong instinct.

The following sections sketch some principles to help reinvigorate environmental law around the world. The focus is on some basic concepts that can guide the transformation of environmental law, rather than attempting to unrealistically elaborate any grandiose blueprints for change.

\section{B. PROXIMITY}

Because of the difficulties humankind faces in cooperating at a large scale, and because globalization allows human civilization to lose sight of local environmental constraints, environmental law-makers should invocate what I label the "proximity principle". It requires that people should rely as much as possible on local environments to meet their needs and to dispose of their wastes. Thus, toxic waste should not be shipped thousands of miles to distant

169 For evidence in the United States, see, e.g., J. CLARENCE DAVIES \& JAN MAZUREK, POLLUTION CONTROL IN THE UNITED STATES: EVALUATING THE SYSTEM (1998); Arnold W. Reitze, A Century of Air Pollution Control Law: What's Worked; What's Failed; What Might Work, 21 ENVTL. L. 1549 (1991).

ROBERT C. ELLICKSON, ORDER WITHOUT LAW: HOW NEIGHBORS SETTLE DISPUTES 40-64 (1991) (discussing resolution of disputes over livestock movements in ranching country).

Many environmentalists, however, stress the importance of ethical change to ensure humankind lives sustainably, and Edward O. Wilson went so far to propose a "biophilia" hypothesis, which posits that humans evolved as animals deeply enmeshed with the intricacies of nature, and that we retain this affinity with nature ingrained in our genotype: EDWARD O. WILSON, BIOPHILIA (1984). 
developing countries for cheap disposal, and consumer goods and services should be provided by local businesses from local materials. One example of this imperative already in place is the slow food movement, which cajoles people to eat organic food produced locally within 100 miles of their homes. ${ }^{172}$ It is dubious to call someone an "organic" consumer who lives in London or New York but consumes a New Zealand apple grown without pesticides that is air freighted a vast distance to their local supermarket.

By putting our senses in proximity to our environmental burden, we are more likely to trigger the kind of deep-seated evolutionary, cognitive and emotional responses that fuel empathy and compassion for other species and nature generally. This is why animal liberationists and some environmental groups try to sensitize the consciousness of people by parading barbarous images of factory farm animals suffering or whales being harpooned, in the hope that we will see the connections between what we eat (or which law-makers we vote for), and the resulting harm. ${ }^{173}$ While empathy is an emotional reflex, having pity may give us a natural foundation for moral virtue and legal sanctions.

While the proximity principle is not yet widely recognized in environmental law, it is most evidently reflected in European Union (EU) law. The approach is implicit in the guiding norms laid down by the EU Treaty for environmental action. ${ }^{174}$ Historically, the notion of the proximity principle has been most closely linked to pollution control and regulation of waste disposal, and is reflected in a number of EU directives. ${ }^{175}$ It serves to promote local self-sufficiency in environmental management and ensure equity by discouraging communities from exporting their waste or other environmental impacts to more vulnerable localities.

To implement the proximity principle more comprehensively, there should also be tighter constraints on international trade including incorporation of more stringent environmental criteria into trade agreements. However, international exchanges of ideas and innovations, such as eco-efficiency technologies, should be encouraged to help societies find solutions to the common problems they confront. Matt Ridley argues that trade and exchange have been crucial to the evolutionary success of human beings: "exchange plays the same role in cultural evolution that sex plays in biological evolution. Sex brings together genetic innovations made in different bodies; trade brings together cultural evolutions made in different tribes". ${ }^{176}$ But trade in hard goods and services should be curbed in the interests of promoting local

172 Bruce Pietrykowski, You Are What You Eat: The Social Economy of the Slow Food Movement, 62 REV. SOCIAL ECON. 307 (2004).

173 See especially JONATHAN S. FOER, EATING ANIMALS (2009); FARLEY MOWAT, SEA OF SLAUGHTER (2003).

174 The relevant part of the Treaty states “... that environmental damage should as a priority be rectified at source": Treaty Establishing the European Community, art. 174(2), 2006 O.J. (C 321E) 37, 68. Perspectives, in REFLECTIONS ON 30 YEARS OF EU ENVIRONMENTAL LAW. A HIGH LEVEL OF PROTECTION? 289, 293 (Richard Macrory ed., 2006). 
environmental self-sufficiency and accountability, with limited exceptions such as helping the destitute in developing countries who are suffering tragic circumstances.

Concomitantly, the proximity principle demands policy changes in a wide range of other environmentally-relevant contexts. For example, environmental controls should extend to financial markets. They enable people to invest through mutual funds or pension plans in economic activities that are undertaken far away, sometimes without investors' knowledge of the nature of the developments and their resulting environmental impacts. The movement for socially responsible investment is starting to challenge this recklessness, but it needs accompanying legal reforms to exert more influence in the market, such as through lender liability for environmental damage, mandatory disclosure of the financial institutions' environmental impacts, and taxation incentives for green investment. ${ }^{177}$

Some environmental issues that transcend local boundaries will continue to demand regional or global-level cooperation, such as to sustainably manage marine fisheries, safeguard globallysignificant carbon sinks, and address other conduct that yields major global externalities. Local communities commonly lack the knowledge and resources to tackle such issues, and cannot easily cooperate to resolve them without higher level decision-making institutions. Furthermore, as Jonathan Weiner explains, the political incentive for local action, such as limiting greenhouse emissions, is hindered when such action would incur local costs for minimal local benefits. ${ }^{178}$ The proximity principle is not per se at odds with the need to consider the biosphere on a planetary scale; it asks us to think globally while acting locally when addressing the environmental impacts of our decisions. But the principle itself does not provide answers to regulation of trans-border environmental activities and impacts. In light of the lessons from evolutionary psychology, international environmental regulation is most likely to flourish when it goes beyond merely stating rules of behavior to establish institutional regimes that foster dialogue, mutual understanding, trust, and reciprocity. Oran Young's work on the design international regimes for environmental governance offers among the most perspicacious insights for achieving such arrangements for higher scale cooperation. ${ }^{179}$

\section{Regime Diversity}

The principle of regime diversity is another seminal building-block for effective environmental governance. The term regime diversity can be defined as the web of governance arrangements

177 BENJAMIN J. RICHARDSON, SOCIALLY RESPONSIBLE INVESTMENT LAW: REGULATING THE UNSEEN POLLUTERS 533-40, 559-67 (2008). 1961, 1966-67 (2007).

179

ORAN R. YOUNG, INTERNATIONAL COOPERATION: BUILDING REGIMES FOR NATURAL RESOURCES AND THE ENVIRONMENT (1989). 
including legal regulation deployed by a society for addressing its environmental challenges. Such diversity on an international scale provides valuable insurance for overcoming complex and dynamic environmental problems. As already discussed in this article, the human condition is not monolithic-there is considerable diversity of behavior among individuals within a given society, as well as broader cultural diversity among different societies. Just as genetic and biological diversity improves the resilience of a species or an ecosystem, behavioral and cultural diversity strengthens the resilience of humankind to meet its problems including the challenge of developing sustainably.

Cultural diversity can manifest in different approaches to environmental governance, including in choice of laws, institutions, and practices. Such regime diversity can give humankind more options to finding answers to its environmental problems. It allows for experimentation with various approaches, and successful solutions can be exported to other societies for adoption. Many of the seminal advances in modern environmental law, such as the precautionary principle, emerged as discrete innovations within individual jurisdictions to be later disseminated around the world. ${ }^{180}$ Regime diversity also improves humankind's resilience to deal with unexpected, adverse changes in social, economic, or environmental conditions that might hinder progress towards sustainability. Thomas Homer-Dixon argues that the resilience of modern civilization to cope with such risks can be strengthened by reducing those social and economic connectivities that can cause cascading failures through closely inter-linked societies and systems. ${ }^{181}$ For example, the financial crisis of 2008-2009 became a larger, global event because of the interconnected financial markets operating in a liberalized, open international economy. ${ }^{182}$ So too, the likelihood or impact of many environmental risks can be minimized if societies can pursue different models of economic development and have different regulatory approaches, so that failure in one nation or community does not affect all equally. This conclusion of course does not imply that local environmental mismanagement occurs without significant trans-border impacts, as is well known from disasters such as at Chernobyl. ${ }^{183}$ International environmental cooperation, as outlined in the previous section, retains a vital role for managing such situations.

One example of how cultural diversity can educate us in alternative approaches to environmental stewardship is the case of indigenous communities, who are seen by some as a paragon of sustainable living. ${ }^{184}$ Richard Nelson writes, "the ethnographic record supports the

180 The precautionary principle was an innovation of German law, and is the English translation of the German phrase "Vorsorgeprinzip": Bernhard W. Wegener, Principles into Practice-The German Case, in REFLECTIONS ON 30 YEARS OF EU ENVIRONMENTAL LAW, supra note 175, at 101, 103.

181 THOMAS HOMER-DIXON, THE UPSIDE OF DOWN: CATASTROPHE, CREATIVITY AND THE RENEWAL OF CIVILISATION 20-21, 115-16 (2006).

182 Id., at 287-88.

183 ALEXEY V. YABLOKOV, VASSILY B. NESTERENKO \& ALEXEY V. NESTERENKO, CHERNOBYL: CONSEQUENCES OF THE CATASTROPHE FOR PEOPLE AND THE ENVIRONMENT (2009). 
existence of a widespread and well-developed tradition of conservation, land stewardship, and religiously based environmental ethics among Native Americans ... we need to rediscover a deep, perhaps spiritually based, affiliation with life" ${ }^{185}$ Their environmental record, nonetheless, suggests that not all indigenous peoples display this ideal. The tendency to sentimentalize them as noble savages living sustainably has been disputed, and William Vickers counters that the conservation practices of indigenous peoples are not a state of being, but, rather, a rational response to changing environmental circumstances. ${ }^{186}$ Apart from the Pleistocene overkill of mega fauna, as previously mentioned, more recent and contemporary evidence casts doubt on the sustainability of all indigenous livelihoods. ${ }^{187}$ Yet, while the lower environmental burden of indigenous peoples compared to Western societies is probably a product of fewer numbers and the limitations of their technologies (rather than any innate ethic of ecological self-restraint), their lifestyles still can provide valuable lessons for others in seeking alternative, more environmentally benign livelihoods.

Environmental lawyers, therefore, should seek to strengthen the legal rights of indigenous peoples and those other groups around the world whose lifestyles are more conducive to sustainability. In Canada, a world leader in this area, legal initiatives such as acknowledgement of aboriginal land title, negotiation of comprehensive land claims agreements, and the First Nations Land Management Act, are among progressive examples of measures to enhance indigenous self-determination in environmental governance. ${ }^{188}$ Through such regimes indigenous participation and values can be expressed and different approaches to natural resource management pursued.

This example also illustrates how the principle of regime diversity must often be linked to strategies for social justice and equality. Communities that are oppressed and marginalized are unlikely to be able to maintain viable governance traditions and practices. Murray Bookchin has also linked improvements in social justice to better environmental practices, since societies wracked by violence and discrimination are unlikely to be particularly attentive to their environment. ${ }^{189}$ In a world marked by gross inequalities between developing and developed countries, the rich and the poor, and racial majorities and minorities, environmental law will

185 Richard Nelson, Searching for the Lost Arrow: Physical and Spiritual Ecology in the Hunter's World, in THE BIOPHILIA HYPOTHESIS 201, 221 (Stephen R. Kellert \& Edward O. Wilson, eds., 1991).

186

William Vickers, From Opportunism to Nascent

The Case of the Siona-Secoya, 5(4) HUMAN NATURE 307 (1994).

187

188

189

RIDLEY, supra note 28 , at 118-19.

Benjamin J. Richardson, The Ties that Bind: Indigenous Peoples and Environmental Governance, in INDIGENOUS PEOPLES AND THE LAW: COMPARATIVE AND CRITICAL PERSPECTIVES 337, 363-65 (Benjamin J. Richardson, Shin Imai \& Kent McNeil eds., 2009).

Bookchin, supra note 126. 
surely struggle to resonate relevance. Environmental law should complement social reforms to reduce these gaps and inequalities through human rights law, international development assistance, and other mechanisms for social justice. While the sustainable development rhetoric of inter- and intra-generational equity suggests that environment policy-makers are already well acquainted with this imperative, ${ }^{190}$ in practice far too many environmental decisions, ranging from the siting of waste dumps to the management of conservation areas, marginalize social justice considerations. ${ }^{191}$

Such reforms would dovetail with some of the lessons of evolutionary psychology. Regime diversity implies a degree of localism in the governance of environmental issues. This creates better opportunities for taking advantage of the altruistic and cooperative impulses of human communities, which are strongest where their members are able to interact frequently and intimately. Regime diversity also allows for a better matching between the governance systems and cultural preferences of each society, rather than imposing uniform approaches at odds with different historical, geographical, and cultural traditions. Combined with the proximity principle, regime diversity provides a crucial pillar for rebuilding environmental law.

\section{CURBING INCREMENTALISM}

A third key objective of environmental law must be to curb the incremental environmental impacts of modern lifestyles. Environmental law does not deal very well with incremental impacts that cumulatively can be over-whelming. Traditionally, environmental regulation was based on an underlying premise that environmental problems are best addressed where they physically occur and where impacts lie, associated with images of fuming smokestacks, leaking pipelines, and the like. Yet, many of today's most urgent environmental problems have emerged slowly and surreptitiously, through cumulative activities from numerous and highly dispersed sources, not effectively targeted by existing point-source regulation. ${ }^{192}$ These include climate change, persistent organic pollutants in the food chain, and erosion of biodiversity. For example, greenhouse gases and ozone-depleting chemicals are invisible. Causal connection is difficult as these insidious environmental problems are often widely disconnected by time and place. Long ecological shadows are also cast by our consumer culture, such as the annual production of billions of plastic bags and bottles, which may end up seemingly "out-of-sight" as detritus floating in the ocean to be swallowed by marine life, or as waste buried in landfill sites that eventually contaminate groundwater reservoirs. ${ }^{193}$ Such incrementalism obscures and

190 Igor Vojnovic, Intergenerational and Intragenerational Equity Requirements for Sustainability, 22(3) ENVTL CONSERVATION 223 (1995).

191 See ROBERT D. BULLARD, DUMPING IN DIXIE: RACE, CLASS, AND ENVIRONMENTAL QUALITY (1990); Davis S. Wilkie, et al., Parks and People: Assessing the Human Welfare Effects of Establishing Protected Areas for Biodiversity Conservation, 20(1) CONSERVATION BIOLOGY 247 (2006).

192 SEE BARBARA ADAM, TIMESCAPES OF MODERNITY: THE ENVIRONMENT AND INVISIBLE HAZARDS (1998).

193 PETER DAUVERGNE, THE SHADOWS OF CONSUMPTION: CONSEQUENCES FOR THE GLOBAL ENVIRONMENT (2008). 
displaces environmental costs, and makes our personal decisions seem inconsequential to the planet. This phenomenon also points to a potential blind-spot of making environmental decisions on solely the basis of the proximity principle, which tends to focus on those activities and impacts which are most visible locally.

Our evolved psychology does not allow us to appreciate such incremental impacts very well. We may understand the message-don't shop with a plastic bag or recycle that plastic bottlebut our habits continue largely unchanged. We tend not to feel morally that there is much at stake in our individual actions. The main triggers for extended altruism are also lacking in such situations where there are no identifiable beneficiaries. The complex multitude of actors involved in such pervasive environmental problems also makes it difficult to identify specific persons or places with which we could "reciprocate" good deeds.

Therefore, environmental policy instruments must do more than target mere end-of-pipe sources. They must also address the underlying processes in the economy that fuel unsustainable practices. Environmental law so far has sought only in limited ways to challenge the curse of incrementalism. In many countries, environmental impact assessment procedures for development projects require proponents to evaluate the projected impacts in light of the cumulative effects. ${ }^{194}$ Authorities have also turned to market-based instruments promising more flexible and cooperative ways to address environmental threats, such as cap-and-trade schemes to limit pollution emissions or natural resources harvested. ${ }^{195}$ However, these instruments tend to work only well in regulating a portion of the market-the big and visible entities, while the little stuff can remain overlooked.

The challenge, thus, is to build an environmental law diaspora, where environmental standards are embedded throughout all spheres of social and economic life. This could be achieved for example through ecological tax reform, which would shift the tax burden from income generation to consumption activities and thereby more comprehensively could create disincentives against many incremental demands on the environment. ${ }^{196}$ Consistent with the proximity principle, much of this diasporic regulation must also manifest at a local level, for example, through land use planning laws that curb urban sprawl. Local-level controls can also sometimes more efficiently respond to local circumstances and environmental pressures.

\footnotetext{
194 In relation to the United States, see Michael D. Smith, Cumulative Impact Assessment under the National Environmental Policy Act: An Analysis of Recent Case Law, 8 ENVTL PRACTICE 228 (2006).

195 See Jon Rosales, Economic Growth and Biodiversity Loss in an Age of Tradable Permits, 20(4) CONSERVATION BIOLOGY 1042 (2006).

196 Benoit Bosquet, Environmental Tax Reform: Does it Work? A Survey of the Empirical Evidence, 34 J. Ecol. Econ. 19 (2000).
} 
An environmental law diaspora may however be institutionally unsustainable without careful design. Pervasive state regulation of personal and market activity poses levels of coerciveness that are likely impracticable and unacceptable to most policymakers, the business sector, and individuals. Regulatory theorists such as Gunther Teubner warn of the burdens of "juridification" when regulation becomes too ambitious and meddlesome. ${ }^{197}$ Social historians such as Joseph Tainter characterize the problem as one where increasing investments by a society in "complexity" to solve its problems lead to diminishing returns and policy failures. ${ }^{198}$ Confronted with mounting environmental stresses, states often prescribe more detailed rules, devise new technologies and commit greater financial resources. Initially, such investments can obtain concrete results (as the "low hanging fruit" is picked first) but gradually they yield ever more meagre results to the point where the remedial costs can become unsustainable to society. Environmental problems such as climate change and the loss of biodiversity are among those that require some enormously complex and costly responses.

To address this challenge therefore probably requires both rethinking basic economic models that shape what we value and what constitutes legitimate development, and embedding regulatory standards at the very point where economic decision making in business corporations and financial institutions arises. Ecological economists such as Herman Daly are leading efforts in this area by advancing proposals for a "steady state economy" and other solutions for limiting incremental economic growth. ${ }^{199}$ Presently, environmental law is largely an imposed "external" set of constraints to economic institutions, rather than an intrinsic element in their formative decision making. The procedures and processes of economic decision making should be revamped to embed sustainability considerations from the outset, to be incorporated into all business decision making. This reorientation could be achieved, for example, by altering the fiduciary duties of corporations and financial institutions so that they would prioritize sustainable development, rather than act for the exclusive benefit of their shareholders, creditors, or other economic beneficiaries. ${ }^{200}$

The above principles and ideas are by no means exhaustive-they simply illustrate the more important aspects of a new agenda of environmental law reform to address fundamentally the maladaptive human condition. Creating more interdisciplinary dialogue is crucial to developing more comprehensive regulatory strategies for sustainability. We need to build new public forums, nationally and globally, to explore and debate legal and other solutions to our environmental challenges. The Millennium Ecosystem Assessment and the Intergovernmental Panel on Climate Change for example have been established to investigate the biophysical aspects of global change, but they hardly look at the ethical, cultural, and psychological

\footnotetext{
197 Gunther Teubner, Juridification: Concepts, Aspects, Limits, Solutions, in A READER ON REGULATION 389 (Robert Baldwin, Colin Scott \& Christopher Hood eds., 1998).

198 JOSEPH TAINTER, WHY COMPLEX SOCIETIES COLLAPSE (1990).

199 HERMAN DALY, STEADY STATE ECONOMICS (2nd. ed., 1991).

200 See the proposals of Benjamin J. Richardson, Putting Ethics into Environmental Law: Fiduciary Duties for Ethical Investment, 46(2) OSGOODE HALL L. J. 243, 277-80 (2008).
} 
dimensions of the creation and resolution of these environmental threats. ${ }^{201}$ The tool-box of environmental law must stimulate more interdisciplinary approaches to environmental decision making, such as using public environmental inquiries. They were used quite successfully in Australia during the 1990s through the former Resource Assessment Commission, ${ }^{202}$ and in Canada in the 1970s, such as the famous Berger inquiry into the proposed Mackenzie Valley Pipeline. $^{203}$ If structured properly, public inquiries can provide a seminal means for interaction and dialogue among people from all walks of life, and the synthesis of different academic disciplines to consider environmental impacts and development choices. In other words, they are decision making forums that might best illuminate some of the insights of evolutionary psychology and other disciplines for understanding human environmental behavior.

\section{PARting ThOUghts}

We must understand the evolutionary basis of our behavior to solve the environmental problems we created. Our biological makeup influences, but neither justifies nor predetermines our environmentally harmful lifestyles. Although evolutionary scientists imply that culture is secondary to biological urges, culture itself is one of the manifestations of the evolution of Homo sapiens sapiens. Essentially, we are born with an ability to behave in certain ways and learn certain things. Nature thus circumscribes rather than determines our possibilities. Humans are genetically wired with certain predispositions, even behavioral, but our intellectual capacity to rationalize allows us to make choices which can influence outcomes. The manifestation of our evolved instincts depends on specific environmental contexts, and even when triggered our evolved adaptations usually give us several possible responses, such as to fight, freeze, or flee when confronted with a dangerous animal.

Concurrently, we should not trivialize our environmental practices and impacts on the basis of some crude reasoning that they simply reflect the laws of natural selection and the workings of nature. Nature is not a moral authority and we shouldn't necessarily derive our values from its workings, such as "survival of the fittest" or "might makes right". We should also be careful when elevating our own moral agency and responsibility that we don't lapse into a perspective of pure cultural relativism without any defensible truths such as regarding the threat of climate change or mass extinction of species. Anthropologists Mary Douglas and Aaron Wildavsky argue that concepts of "pollution" and "harm" should be seen as cultural constructs rather than purely objective realities, whose meaning is dependent on their social context and time. ${ }^{204}$

\footnotetext{
201

Paul R. Ehrlich \& Donald Kennedy, Millennium Assessment of Human Behavior, 309 SCIENCE 562 (2005).

202 Benjamin J. Richardson \& Ben Boer, Contribution of Public Inquiries to Environmental Assessment, 2(2) AUSTRALIAN J. ENVTL MAN. 90 (1995).

203 THOMAS R. BERGER, NORTHERN FRONTIER, NORTHERN HOMELAND: THE REPORT OF THE MACKENZIE VALLEY PIPELINE INQUIRY (1977). 
Conceivably, from this perspective, a society might even aspire to transform nature into an artificial dystopia of plastic trees and genetically engineered animals. While evolutionary psychology alerts us to flaws in how humans sometimes perceive their environmental impacts and risks, it does not imply that those impacts and risks should be treated as purely value judgments. We should remain open to dialogue about the contested scientific research behind many environmental problems and be attentive to cultural biases at work.

By conscious cultural evolution and education, we can act on that environmental knowledge to devise solutions to the problems we spawned. Our ability to reason abstractly and emotionally about the impact of our behavior on one another and nature generally gives us unique means to address those impacts. As a moral animal, we have the capacity to consciously shape the well-being of the planet. The "is" and the "ought" of human nature may be logically separable, but they are not so far removed as to preclude enlightened reform. Acting ethically towards the environment does not involve an insurmountable struggle with our deepest natures. Biology, ethology, anthropology, and evolutionary psychology provide information about human nature that can help make environmental law more behaviorally effective. But twentieth century history painfully shows that there are limits to the power of culture in changing human nature. Attempts to remold human nature according to a utopian vision have given rise to such horrors as Stalin's totalitarianism and Pol Pot's genocide. ${ }^{205}$ The renewal of environmental law should thus go hand-in-hand with democratic and social justice policies.

Humankind's burdensome relationship with nature poses the greatest challenge in our evolutionary history. From our own self-interest as a species, what is at stake is our very future. In a rather frightening observation, Jared Diamond in the Rise and Fall of the Third Chimpanzee speculates why we have never encountered intelligent life from other planets. ${ }^{206}$ He suggests that all highly intelligent life might face an evolutionary dead-end, because once a species evolves the capacity to destroy its environment and itself-such as by nuclear weapons and other transformative technologies-it is perhaps only a matter of time before by conscious choice or reckless indifference it does so. The most successful species, believes Diamond, are not the cleverest but the relatively "dumb and clumsy rats and beetles". ${ }^{207}$

If we despairingly conclude that it is too late or impossible to stop the juggernaut of environmental destruction through our laws and other institutions, we might take solace that nature should recover in a world without us. If we can't live in community with nature, at least nature should live without us. In his best-seller, The World Without Us, Alan Weisman predicts that, liberated from humankind's environmentally poisonous burden, the planet would quickly recover from most of the damage within a few thousand years, and within a few million years only the most virtually indestructible plastics and radioactive materials would linger on,

\footnotetext{
205 DIAMOND, supra note 37, at 213-14.

206 ROSEMARY H.T. O'KANE, TERROR, FORCE AND STATES: THE PATH FROM MODERNITY 101-34, 179-94 (1996).

207 Id., at 213.
} 
hopefully buried out of harms way. ${ }^{208}$ The ability of nature to recover quickly from the worst assaults is already evident; such as around Chernobyl, where animal life has blossomed after the 1986 deadly radiation leak in an area where few humans still dare to visit.

But hopefully humankind through its environmental laws will be able to live with, rather than apart from, nature. While human beings have a dark side, as portrayed in Golding's Lord of the Flies, our biological and cultural legacy is somewhat more complicated than this story and we have evolved a benevolent side. In order to overcome the damp squib that modern environmental law has become, lawyers must nurture our kinder traits before it is too late.

208 ALAN WEISMAN, THE WORLD WITHOUT US (2007). 